\title{
Underlying mechanisms of glucocorticoid-induced $\beta$-cell death and dysfunction: a new role for glycogen synthase kinase 3
}

\author{
Etienne Delangre ${ }^{1}$, Junjun Liu ${ }^{1,3}$, Stefania Tolu ${ }^{1}$, Kamel Maouche ${ }^{1}$, Mathieu Armanet ${ }^{2}$, Pierre Cattan ${ }^{2}$, Gaëlle Pommier ${ }^{1}$, \\ Danielle Bailbé ${ }^{1}$ and Jamileh Movassat iD $^{1 凶}$
}

(c) The Author(s) 2021

Glucocorticoids (GCs) are widely prescribed for their anti-inflammatory and immunosuppressive properties as a treatment for a variety of diseases. The use of GCs is associated with important side effects, including diabetogenic effects. However, the underlying mechanisms of GC-mediated diabetogenic effects in $\beta$-cells are not well understood. In this study we investigated the role of glycogen synthase kinase 3 (GSK3) in the mediation of $\beta$-cell death and dysfunction induced by GCs. Using genetic and pharmacological approaches we showed that GSK3 is involved in GC-induced $\beta$-cell death and impaired insulin secretion. Further, we unraveled the underlying mechanisms of GC-GSK3 crosstalk. We showed that GSK3 is marginally implicated in the nuclear localization of GC receptor (GR) upon ligand binding. Furthermore, we showed that GSK3 regulates the expression of GR at mRNA and protein levels. Finally, we dissected the proper contribution of each GSK3 isoform and showed that GSK3 $\beta$ isoform is sufficient to mediate the pro-apoptotic effects of GCs in $\beta$-cells. Collectively, in this work we identified GSK3 as a viable target to mitigate GC deleterious effects in pancreatic $\beta$-cells.

Cell Death and Disease (2021)12:1136; https://doi.org/10.1038/s41419-021-04419-8

\section{INTRODUCTION}

Glucocorticoids (GCs) are steroid hormones produced by the adrenal gland, under the control of the hypothalamo-pituitary axis [1]. They regulate a large number of physiological processes and are widely used in therapy for their anti-inflammatory, immunomodulatory and anti-allergic properties [2]. Their clinical usage remains irreplaceable, especially in case of transplantation [3], or for treating chronic inflammatory diseases such as rheumatoid arthritis [4], asthma [5] or multiple sclerosis [6]. GCs effects are mainly mediated by the glucocorticoid receptor (GR), which upon activation and nuclear translocation acts as a transcription factor, regulating the expression of a large spectrum of genes. In the absence of GCs, the GR is mainly located in the cytoplasm, in a macromolecular complex with chaperone proteins [7]. Its liganddependent nuclear translocation is known to be regulated by post-translational modifications, especially by phosphorylation [8].

Unfortunately, the therapeutic benefits of GCs are accompanied with serious side effects, particularly in the context of chronic treatments. Osteoporosis [9], loss of muscular mass [10] or a disruption in glucose metabolism, including diabetes [11] are among the most common side effects which are also found in Cushing's disease suffering patients [12].

The exact incidence of GC-induced diabetes is unknown. Hjelmesaeth and coworkers have shown that about $20 \%$ of patients treated with GC-based therapy after renal transplantation develop diabetes [13]. Overall, up to $2 \%$ of the cases of diabetes might be associated with GC therapies [14]. Moreover, in human, one single dose of $75 \mathrm{mg}$ prednisolone, a synthetic GC, induced glucose intolerance [15]. GCs are known to have adverse effects on pancreatic $\beta$-cell homeostasis, affecting their development $[16]$, their secretory function $[17,18]$ and their survival [19]. These defects could contribute to the pathogenesis of GC-induced diabetes.

A better understanding of the complex regulation of $\mathrm{GC}$ signaling and its crosstalk with other intracellular pathways may provide the opportunity to minimize the undesirable effects of GCs and improve their benefit-risk profile for prolonged therapeutic applications.

In this study, we investigated the possible implication of Glycogen Synthase Kinase 3 (GSK3) in the mediation of diabetogenic effects of GCs in $\beta$-cells. GSK3 is a serine/threonine kinase, initially described as the kinase inhibiting Glycogen Synthase in the insulin signaling pathway [20]. GSK3, with two isoforms, GSK3a and GSK3 $\beta$, encoded by two different genes, is implicated in a large variety of cellular processes, including proliferation, migration, and metabolism [21]. In some cellular systems, both in rodents [22] and humans [23], GSK3 has been reported to interact with the GC signaling pathway through the regulation of GR nuclear localization and the modulation of its transcriptional activity. However, to date, despite the independent roles of GCs and GSK3 in $\beta$-cell biology, the interplay between these two crucial pathways has not been elucidated in these cells. In this study, through pharmacological and genetic inhibition of GSK3, we investigated its role in the mediation of deleterious

\footnotetext{
${ }^{1}$ Université de Paris, BFA, UMR 8251, CNRS, Team « Biologie et Pathologie du Pancréas Endocrine », Paris, France. ${ }^{2}$ Cell Therapy Unit, Saint-Louis hospital, AP-HP, and Université de Paris, Paris, France. ${ }^{3}$ Present address: Shandong Institute of Endocrine \& Metabolic Diseases, Shandong First Medical University \& Shandong Academy of Medical Sciences, Jinan,

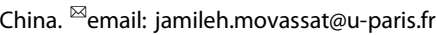
Edited by Professor Massimiliano Agostini
} 
effects of GCs in $\beta$-cells. We showed for the first time that GSK3 is implicated in the adverse effects of GCs on survival and the secretory function of pancreatic islets. Moreover, we dissected some of the mechanisms underlying the crosstalk between GSK3 and GCs pathway, and uncovered the proper contribution of GSK3 $a$ and GSK3 $\beta$ isoforms to this process.

\section{RESULTS}

GSK3 inhibition protects $\boldsymbol{\beta}$-cells from Dexa-induced cell death First, we examined the effect of dexamethasone (Dexa), a widely used GC analog, on cell apoptosis in the $\beta$-cell line INS-1 832/13. After $24 \mathrm{~h}$ of treatment, Dexa induced cell death, as reflected by the increased incorporation of 7-AAD in INS-1 832/13 cells (Fig. 1A, B). Interestingly, the inhibition of GSK3 by SB216763 reduced the Dexa-induced cell death, while it had no effect on cell death in cells not exposed to Dexa. This effect on cell apoptosis was confirmed by the Annexin V-FITC incorporation assay (Fig. 1C and Supplemental Fig. S1).

Next, in order to investigate cell apoptosis induced by Dexa in pancreatic islets isolated from Wistar rats, we performed TUNEL staining in islet sections (Fig. 1D, E). Dexa strongly increased the number of TUNEL positive cells in islets. The treatment of islets with GSK3 inhibitors, either $\mathrm{LiCl}$ or SB216763, significantly decreased the Dexa-induced apoptosis in islet cells, as reflected by a significant decrease of the number of TUNEL-positive cells, reaching a level similar to that observed in control islets which were not treated with Dexa. These results suggest the implication of GSK3 in the induction of cell death by Dexa in $\beta$-cells.

Apoptosis is regulated by the $\mathrm{Bcl}-2$ family of proteins, including pro-apoptotic factors such as Bim or anti-apoptotic factors such as Bcl-2. Here, in INS-1 832/13 and in islets, Dexa increased mRNA and protein levels of Bim and decreased those of $\mathrm{BCl}-2$, suggesting the activation of apoptosis (Fig. 1F-l). The inhibition of GSK3 in INS-1 832/13 and islets, either with $\mathrm{LiCl}$ or with SB216763 abrogated the over-expression of Bim induced by Dexa, whereas it did not change the down-regulation of $\mathrm{BCl}-2$.

It has been reported that the GC-induced apoptosis is associated with the increase of oxidative stress in $\beta$-cells [24]. We assessed the expression of some of the mediators of these pathways in INS-1 832/13 cells. We found no significant changes in the expression of NOX4, SOD1, SOD2, in cells treated with Dexa. Moreover, the expression of $C H O P$, a marker of ER stress was unaffected following Dexa treatment (Supplemental Fig. S2).

\section{GSK3 inhibition prevents the Dexa-induced impairment of insulin secretion in islets}

GCs are known to impair $\beta$-cell secretory function $[17,18]$. In our study, rat islets exposed to Dexa showed decreased insulin secretion in response to glucose, compared to untreated islets (Fig. 2A, B). Insulin secretion was restored in Dexa-treated islets following GSK3 inhibition with $\mathrm{LiCl}$ or SB216763 (Fig. 2A, B). Interestingly, the impairment of insulin secretion induced by Dexa treatment was associated with the upregulation of the expression of $K v 1.5$, a potassium channel which negatively regulates insulin secretion, and SGK1, which controls the activity of Kv1.5 (Fig. 2C). The inhibition of GSK3 partially reversed the upregulation of these factors.

\section{GC signaling does not strongly affect the expression of GSK3, neither its activity}

Studies in other cell types have shown that GCs can regulate GSK3 activity [25]. Here, we investigated the effects of Dexa on both GSK3 expression and activity. First, we showed that treatment of INS-1 832/13 cells or primary islets with Dexa did not result in significant changes in mRNA (Fig. 3A, B) and protein levels of GSK3 $a$ or GSK3 $\beta$ (Fig. 3C-F), although in islets, the expression of GSK3a tended to increase slightly but not significantly (Fig. 3B).
GSK3 activity is regulated by phosphorylation. The phosphorylation of serine 9 (S9) in GSK3 $\beta$ and serine 21 (S21) in GSK3a are known to decrease their activity. Dexa treatment in INS-1 832/13 cells did not change the levels of phosphorylated S9 and S21 in GSK3 $\beta$ and GSK3a respectively (Fig. 3C, D). In islets, the phosphorylation of GSK3 $\beta$ was not significantly affected, while the phosphorylation of GSK3a was slightly but significantly decreased, reflecting an increased activity of this isoform (Fig. 3E, F).

\section{GSK3 participates to the nuclear localization of GR induced by} Dexa

GCs signaling implicates the nuclear localization of GR upon binding to GC. We performed cell fractionation experiments to separate different cellular compartments. Following $3 \mathrm{~h}$ of treatment with Dexa and/or SB216763, the cytoplasmic and nuclear fractions of INS$1832 / 13$ cells were separated, and the purity of fractions was confirmed by the immuno-detection of nuclear marker histone $\mathrm{H} 3$ and cytoplasmic marker tubulin, as shown in Fig. 4A.

As expected, Dexa treatment strongly induced the nuclear translocation of the GR, as shown by immuno-detection of the GR in the nuclear fraction by western blot, and by immunofluorescent staining (Fig. 4A, B). Treatment with SB216763 slightly but reproducibly reduced the nuclear level of GR protein in Dexatreated cells, as shown by the decreased nucleo-cytoplasmic ratio of GR (Fig. 4A). Immunofluorescence staining of GR confirmed these results (Fig. 4B). Moreover, GSK3 $\alpha$ and GSK3 $\beta$ localization were monitored and we found no changes in their sub-cellular localization following Dexa treatment (Fig. 4C, D). However, it should be noted that there was an important heterogeneity in this parameter between the independent experiments.

GSK3 inhibition decreases the expression of GR in INS-1 832/ 13 cells as well as in rat and human islets

In addition to the evaluation of GSK3 expression following Dexa treatment described above, we assessed the mRNA and protein levels of GR upon GSK3 inhibition. We found that SB216763treated INS-1832/13 cells exhibited decreased levels of GR mRNAs and proteins (Fig. 5A, B). Dexa-treated INS-1 832/13 cells also showed decreased GR protein level, likely reflecting an adaptive mechanism [26]. However, a cumulative effect was observed in Dexa + SB216763 condition in comparison to Dexa alone, pointing to a proper implication of GSK3 in this phenomenon. Similar to what we found in INS-1 832/13 cells, GSK3 inhibition significantly reduced GR expression in islets at mRNA (Fig. $5 \mathrm{C}$ ) and protein levels (Fig. 5D). Moreover, we assessed the mRNA level of $\mathrm{GR}$ in human islets treated or not with $\mathrm{LiCl}$. As found in rat islets, the mRNA level of GR was significantly decreased in human islets upon GSK3 inhibition with $\mathrm{LiCl}$ (Fig. 5E).

\section{GSK3 $\beta$ has a major role in GR expression and its downregulation is sufficient to abrogate GC-induced $\beta$-cell death}

Because pharmacological inhibitors used in this study ( $\mathrm{LiCl}$ and SB216763) inhibit both GSK3a and GSK3 $\beta$ isoforms, we used genetic approaches to further dissect the proper role of each isoform in the regulation of the GR expression. Using isoformspecific siRNAs, we knocked down GSK3a or GSK3 $\beta$ in INS-1 832/13. First, we validated by western blot the efficacy of siRNAs in reducing each targeted isoform (Fig. 6A). Furthermore, to rule out a possible compensatory expression between isoforms, we monitored the levels of the non-targeted isoform following the use of the respective GSK3 isoform-specific siRNAs (Fig. 6A). Following these validation steps, we monitered GR protein level by westernblotting. We found that the down-regulation of GSK3 $\beta$, but not GSK3a, is sufficient to reduce GR protein levels in INS-1 832/13 cells (Fig. 6B), to a similar extent as that observed with pharmacological inhibitors. Thereafter, we focused on GSK3 $\beta$ and created a most efficient downregulation system, using shRNA strategy. We used 
A
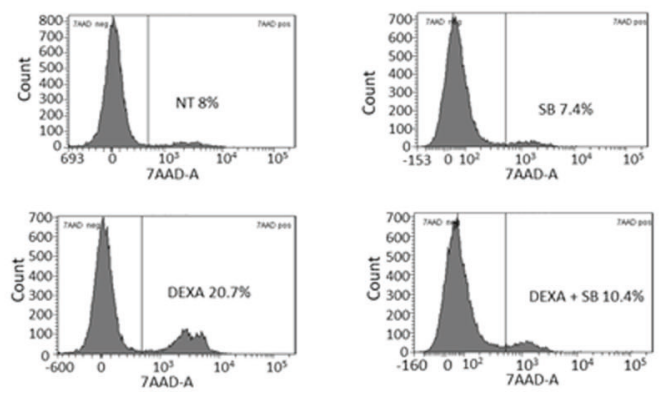

D
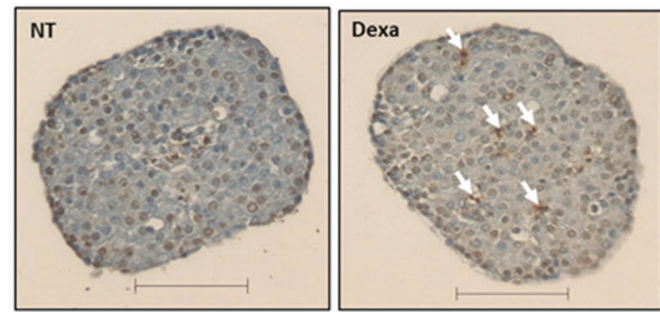

INS-1
F

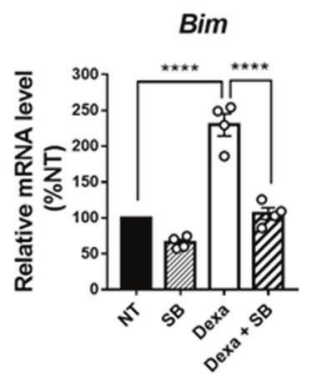

H

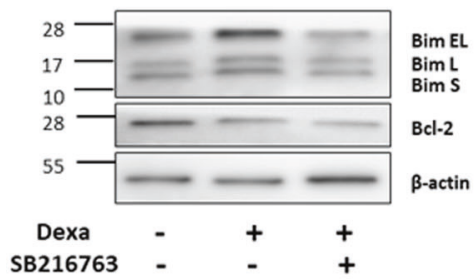

BIM
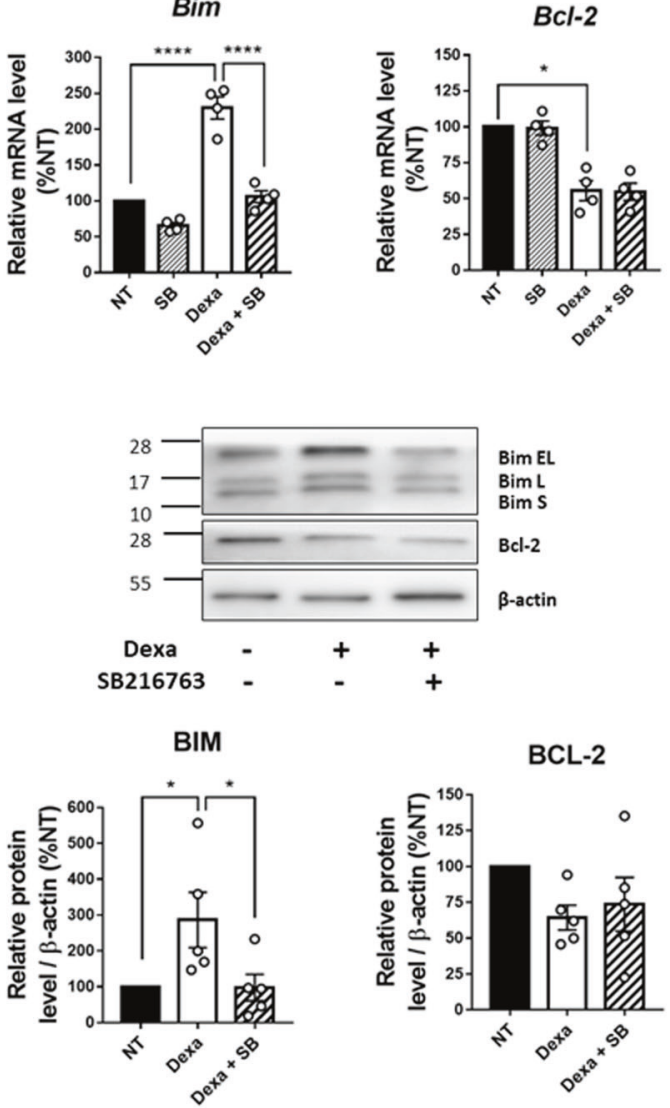

B

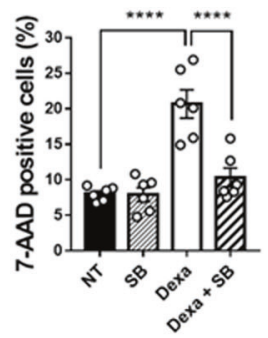

C

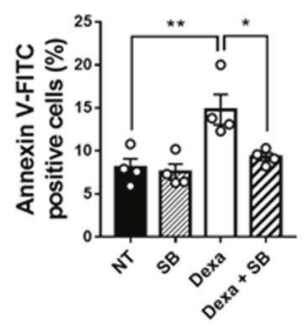

E

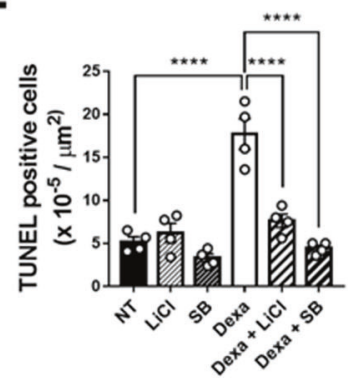

G

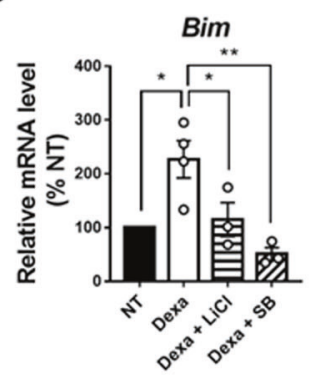

$B C l-2$
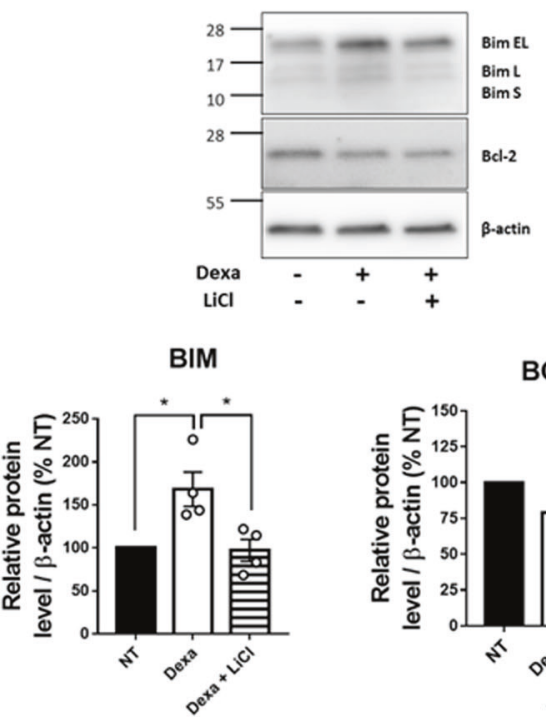

BCL-2

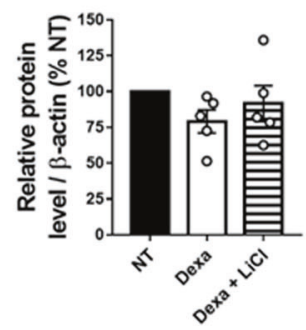

GSK3 $\beta$-specific shRNA expression vectors (2 different sequences) and produced pGFP-C lentiviral transduction particles. After viral infection of INS-1 832/13 cells, we validated their efficacy by showing that both GSK3 $\beta$-specific shRNA sequences efficiently decreased mRNA levels of GSK3 $\beta$, without alterating the levels of GSK3a mRNAs (Fig. 6C). The efficiency of lentiviral infection does not reach $100 \%$ in INS-1 $832 / 13$ cells. To precisely evaluate the role of GSK3 $\beta$ in the regulation of GR expression, we decided to work on cells with effective GSK3 $\beta$ knockdown. We GFP-sorted shGSK3 $\beta$ infected cells, and performed immunoblotting for GR in the GFPpositive population. We showed that in these cells, the expression of GR was reduced by $50 \%$ (Fig. 6D). 
Fig. 1 Treatment with $\mathrm{LiCl}$ or SB216763 decreases Dexa-induced cell death in INS-1 832/13 cell line and in rat islets. A Cell death was assessed by 7-AAD incorporation measured by flow cytometry after $24 \mathrm{~h}$ incubation with or without Dexamethasone (Dexa) and $27 \mathrm{~h}$ incubation with or without SB216763 (SB) in INS-1 832/13 cells. B Quantification of 7-AAD positives INS-1 832/13 cells $(n=6)$. C Cell apoptosis was evaluated by Annexin V-FITC incorporation assay. Annexin V-FITC positive cells were measured by flow cytometry after $24 \mathrm{~h}$ incubation with or without Dexamethasone (Dexa) and $27 \mathrm{~h}$ incubation with or without SB216763 (SB) in INS-1 832/13 cells ( $n=4)$. D Representative images of TUNEL-positive cells in islets, after $24 \mathrm{~h}$ incubation with or without Dexamethasone (Dexa), and $27 \mathrm{~h}$ incubation with or without LiCl. The TUNEL-positive nuclei are stained in brown. White arrows show positive cells. Scale bar: $200 \mu \mathrm{m}$. E Quantification of TUNEL-positive cells in islets $(n=4)$ after $24 \mathrm{~h}$ incubation with or without Dexamethasone (Dexa) and $27 \mathrm{~h}$ incubation with or without LiCl or SB216763 (SB). More than 20 islets per condition were counted. F Relative mRNA levels of Bim and Bcl-2, measured by qPCR $(n=4)$ in INS-1 832/13, after $24 \mathrm{~h}$ incubation with or without Dexamethasone (Dexa) and $27 \mathrm{~h}$ incubation with or without SB216763 (SB). Results are expressed as percentage of NT condition for each independent experiment. G Relative mRNA levels of Bim and $B C l-2$, measured by qPCR $(B i m: n=3-4 ; B C l-2=3-5)$ in islets, after $24 \mathrm{~h}$ incubation with or without Dexamethasone (Dexa) and $27 \mathrm{~h}$ incubation with or without LiCl or SB216763 (SB). Results are expressed as percentage of NT condition for each independent experiment. Cyclophilin $A$ is used as housekeeping gene in figure $\mathbf{F}$ and $\mathbf{G}$. $\mathbf{H}$ Representative Western Blot (top) and quantification (bottom) of Bim and Bcl-2 protein levels in INS-1 832/13 cells after 24 h incubation with or without Dexamethasone (Dexa) and $27 \mathrm{~h}$ incubation with or without SB216763 (SB) $(n=5)$. $\beta$-actin is used as loading control. Results are expressed as percentage of NT condition for each independent experiment. I Representative Western Blot (top) and quantification (bottom) of $\mathrm{Bim}$ and $\mathrm{BCl}-2$ protein levels in islets after $24 \mathrm{~h}$ incubation with or without Dexamethasone (Dexa) and $27 \mathrm{~h}$ incubation with or without LiCl (Bim $n=4 ; \mathrm{Bcl}-2 n=5$ ). $\beta$-actin is used as loading control. Results are expressed as percentage of NT condition for each independent experiment. Results are shown as means \pm S.E.M. $n$ represents the number of independent experiments. ${ }^{*} p<0.05 ;{ }^{* *} p<0.01 ;{ }^{* * * *} p<0.0001$.

Next, we carried out additional experiments to determine whether GSK3 $\beta$ knockdown can oppose the GC-induced cell death in INS-1 832/13 cells. We showed that in GFP-positive cells, which represent cells expressing GSK3 $\beta$ shRNAs, the percentage of 7-AAD positive cells following Dexa treatment was significantly lower compared to the percentage found in Dexa-treated cells infected with scrambled shRNAs, suggesting that GSK3 $\beta$ mediates the pro-apoptotic effects of Dexa in $\beta$-cells (Fig. $6 \mathrm{E}$ ). Interestingly, the knockdown of GSK3 $\beta$ alone produced the same protective effects against GC-induced cell death, as those observed with pharmacological inhibitors (Fig. 1A, B), supporting yet the specific implication of the $\beta$ isoform in this process.

\section{DISCUSSION}

Diabetogenic effects of GCs are largely documented [14, 27-30]. Chronically high levels of GCs, such as those observed in patients suffering from Cushing's syndrome [31], or in case of prolonged administration of GCs for therapeutic purposes, result in metabolic disturbances which are in part due to their deleterious effects on pancreatic $\beta$-cells. GCs are described to alter both $\beta$-cell survival and secretory function in humans and rodents, in most studies $[15,17-19,32-35]$, although a limited number of studies report the opposite $[36,37]$. While the impairment of $\beta$-cell function and survival by GCs has been extensively documented, to date, there is a dearth of information abouth the crosstalk between GCs signaling and GSK3 in this cell type. Only one study has investigated the implication of GSK3 in the GC-induced $\beta$-cell apoptosis [38]. However, this study has not been conducted in islets but only in a non-specified clone of INS-1 cell line and did not address the implication of GSK3 in insulin secretion, neither the proper contribution of GSK3 $\beta$ and GSK3a. In the present study, we unraveled for the first time the mechanisms underlying the implication of GSK3 in the adverse effects of GCs on $\beta$-cells, and provided evidence for the relevance of targeting GSK3 as a means to preserve both $\beta$-cell survival and secretory function, in the context of GC excess. First, using pharmacological and genetic tools, we showed that the pro-apoptotic effects of GCs in $\beta$-cells can be reversed by GSK3 inhibition. The underlying mechanisms of the GC-mediated $\beta$-cell apoptosis are only partially known. It is generally admitted that this process takes place mostly through the activation of the intrinsic apoptotic pathway in $\beta$-cells $[19,39,40]$, although one study showed recently an effect on the extrinsic pathway [41]. We therefore investigated the expression of members of bcl-2 family of proteins, namely Bim and $\mathrm{BCl}-2$, which are key players in the GC-induced intrinsic apoptotic pathway $[19,40]$. We showed that GSK3 is implicated in the Dexainduced upregulation of Bim, but not in the downregulation of $\mathrm{Bcl}-2$ induced by Dexa. These results are in line with a previous study in a lymphoma cell line, where only the upregulation of Bim induced by GCs was dependent on GSK3 [42]. This could be explained by the fact that, as reported by Rogatsky and colleagues, GSK3 controls the transactivation activity of GR in rodent cells, via the phosphorylation of Thr171, whereas it does not impact the transrepression activity of the GR on AP-1 [43].

The inhibitory effect of GCs on insulin secretion has been reported both in rodent and human islets $[15,17]$. Some of these effects are mediated by the induction of the expression of SGK1 and $K v 1.5$, which control the $\mathrm{K}^{+}$outflow in $\beta$-cells and therefore reduce insulin secretion in vitro in INS-1 cells and in vivo [33,44]. In our study, we confirmed the effects of Dexa on the impairment of the glucose-induced insulin secretion and the stimulation of SGK1 and KV1.5 expression in rat islets. Importantly, we show for the first time that pharmacological inhibition of GSK3 by either $\mathrm{LiCl}$ or SB216763 nearly normalized the glucose-induced insulin secretion in Dexa-treated islets. Furthermore, associated with the recovery of normal insulin secretion, the upregulation of SGK1 and Kv1.5 by Dexa was abrogated by GSK3 inhibitors. The mechanisms underlying the interactions between GSK3 and the GCs pathway have been investigated in several cell systems [22, 23, 43, 45]. However, despite the central roles of both GSK3 [46-50] and GCs $[15,17,19,51]$ in $\beta$-cell growth, survival and secretory function, their crosstalk in these cells has not been addressed. To the best of our knowledge, the present study is the first to uncover several aspects of the complex interplay between GSK3 and the GC pathway in $\beta$-cells. First, since GR acts as a regulator of gene transcription, we asked whether the activation of GR by Dexa could affect the expression of GSK3 $\beta$ and GSK3a. We found that the expression of neither of GSK3 isoforms was affected by Dexa treatment in terms of mRNAs nor proteins. As an additional mechanism, GSK3 $\beta$ activity has been reported to be enhanced by GCs through the reduction of the phosphorylation of Ser9 residue of GSK3 $\beta[25,38,52-55]$, hence increasing its activity. Since GSK3 is a negative regulator of growth and survival in $\beta$-cells [46-50], we hypothesized that GCs pro-apoptotic effects could be mediated partly by the stimulation of GSK3 activity upon GC treatment. Here, we showed that GSK3 phosphorylation status was not affected by Dexa in INS-1 832/13 cells. However, in rat islets, while GSK3 $\beta$ phosphorylation on Ser9 was not affected, we found a slight but significant decrease of GSK3a phosphorylation on Ser21, suggestive of its increased activity induced by Dexa, although this mechanism is likely to play a minor role, if any, given the small difference observed between Dexa group and the untreated group.

Most cellular effects of GCs are mediated by the nuclear translocation of GR upon binding of its ligands. Previous studies 
A

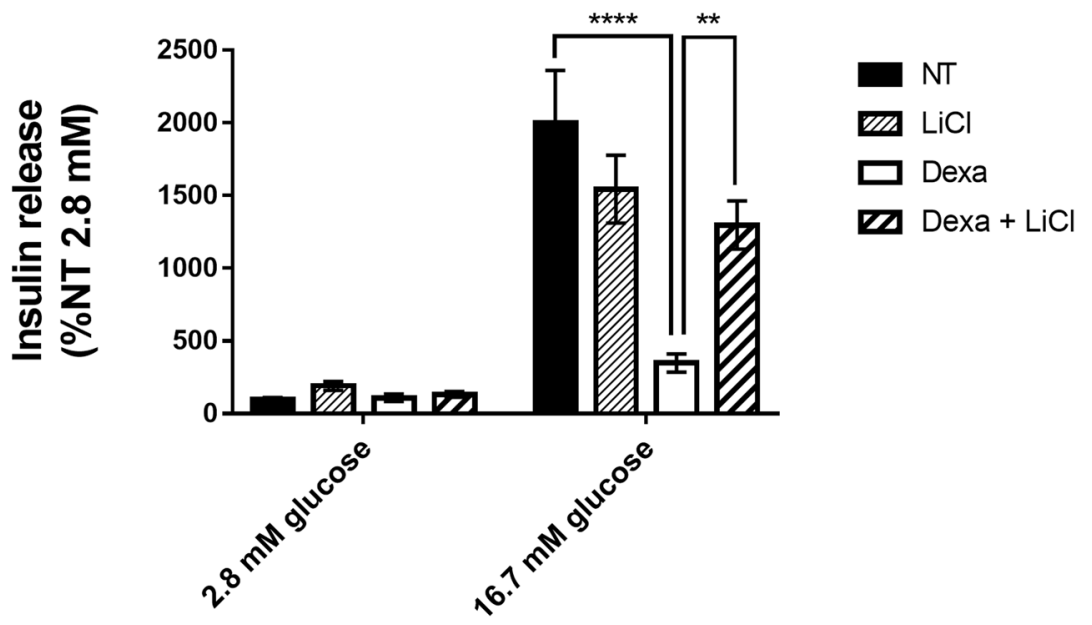

B

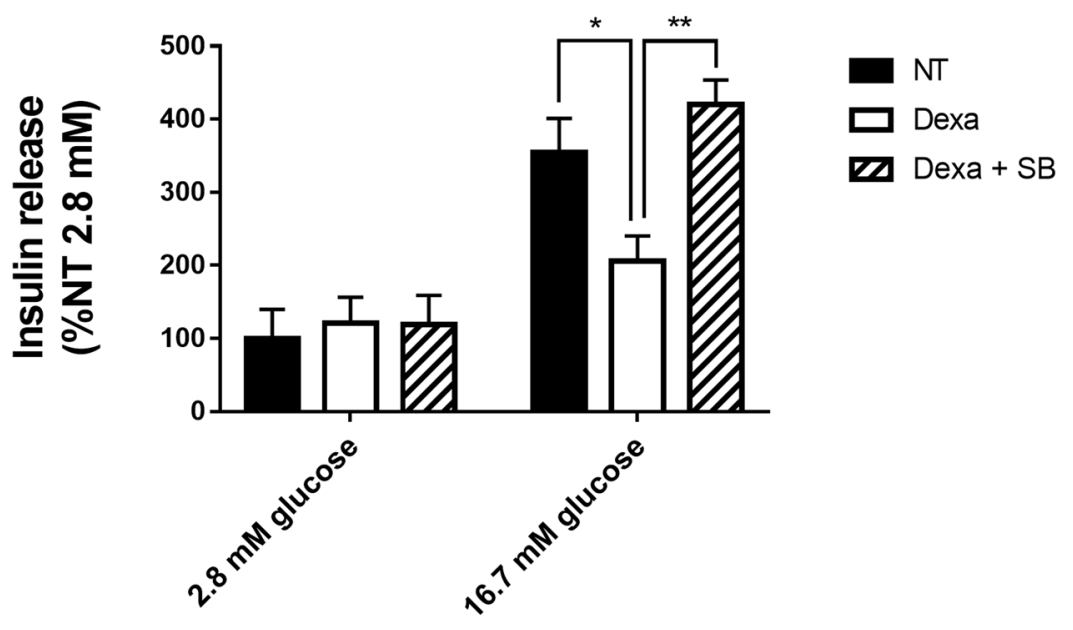

C

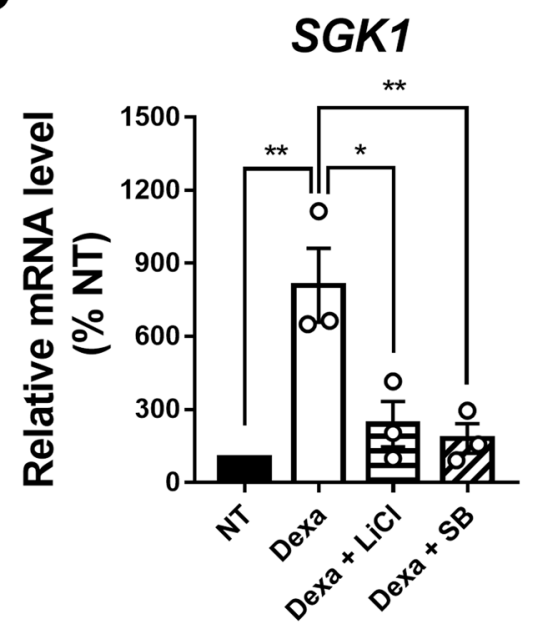

have shown that GSK3 participates to the GR nuclear localization in human osteoblasts [23] and in human lymphocytes [22]. In our study, we showed for the first time in $\beta$-cells, that the inhibition of GSK3 slightly but reproducibly reduced GR's nuclear localization. However, this mechanism could only partly account for the mitigation of GCs effects by GSK3 inhibitors in $\beta$-cells. Importantly, on the other hand, we consistently found that both in rat and human islets, as well as in INS-1 832/13 cells, GSK3 inhibition resulted in a significant decrease of the expression of GR, both at mRNA and protein levels. Interestingly, this mechanism could be 
Fig. 2 Treatment with $\mathrm{LiCl}$ or SB216763 improves insulin secretion in Dexa condition in rat islets. A Measurement of insulin secretion ( $n=$ 5) in rat islets after $24 \mathrm{~h}$ incubation with or without Dexamethasone (Dexa) and $27 \mathrm{~h}$ incubation with or without LiCl. Insulin secretion is assessed in medium containing $2.8 \mathrm{mM}$ glucose or $16.7 \mathrm{mM}$ glucose. Insulin in the medium was measured by ELISA and normalized to the DNA content. Results are expressed as percentage of NT $2.8 \mathrm{mM}$ condition. B Measurement of insulin secretion $(n=5)$ in rat islets after $24 \mathrm{~h}$ incubation with or without Dexamethasone (Dexa) and $27 \mathrm{~h}$ incubation with or without SB216763 (SB). Insulin secretion is assessed in medium containing $2.8 \mathrm{mM}$ glucose or $16.7 \mathrm{mM}$ glucose. Insulin in the medium was measured by ELISA and normalized to the DNA content. Results are expressed as percentage of NT $2.8 \mathrm{mM}$ condition. C Relative mRNA levels of Sgk1 and Kv1.5, measured by qPCR ( $n=3$ ) in islets, after $24 \mathrm{~h}$ incubation with or without Dexamethasone (Dexa) and $27 \mathrm{~h}$ incubation with or without $\mathrm{LiCl}$ or SB216763 (SB). Cyclophilin A is used as housekeeping gene. Results are expressed as percentage of NT condition for each independent experiment. Results are shown as means \pm S.E. M. $n$ represents the number of independent experiments. ${ }^{*} p<0.05 ;{ }^{* *} p<0.01 ;{ }^{* * *} p<0.001 ;{ }^{* * * *} p<0.0001$.

$\beta$-cell specific since in others cell system GSK3 inhibition did not result in downregulation of GR $[22,23,43]$. These are novel and important findings, which have not been reported elsewhere. In light of these findings, we could speculate that one of the multiple roles of GSK3 in $\beta$-cells could be the maintenance of GR at an optimal level, thus contributing, in addition to other mechanisms, to the deleterious effects of GCs on both $\beta$-cells survival and insulin secretion. This unexpected role of GSK3 in $\beta$-cells supports its relevance as a target to alleviate the side effects of GCs. The mechanisms through which GSK3 regulates the expression of GR are not known. It could be speculated that GSK3 would indirectly modulate the transcription of GR gene, and/or the stability of GR mRNA and/or protein in the cell, known to be influenced by its phosphorylation status [56].

Finally, the other major and novel finding of our study was the unraveling of the respective contribution of GSK3 isoforms $a$ and $\beta$, to the mediation of pro-apoptotic effects of GCs in $\beta$-cells. Only few studies in other cells systems have investigated the isoformspecific interaction of GSK3 with the GC pathway, and they led to discordant conclusions $[22,45]$. In the present study, through isoform-specific genetic downregulation, we showed for the first time that the knockdown of GSK3 $\beta$ isoform, and not that of GSK3a, led to a significant decreased expression of GR in $\beta$-cells. Moreover, GSK3 $\beta$ knockdown alone resulted in the abrogation of the pro-apoptotic effects of Dexa, to the same extent as the effects of the pharmacological inhibitors. While the contribution of GSK3a cannot be completely ruled out based on our data, we propose GSK3 $\beta$ as the main GSK3 isoform implicated in the GC-induced cell death in $\beta$-cells.

To sum up, this study provides solid evidence for the central role of GSK3 in promoting the diabetogenic effects of GCs in $\beta$-cells, both in term of survival and insulin secretion. Importantly, we unraveled for the first time some of the mechanisms underlying GR-GSK3 crosstalk in $\beta$-cells, and identified GSK3 $\beta$ as the main isoform contributing to GC-induced $\beta$-cell death.

GCs are widely prescribed for their anti-inflammatory and immunosuppressive properties as treatment for a variety of diseases, including diseases with no alternative therapies. Given the serious diabetogenic side effects of GCs, it is crucial to find new strategies to circumvent the adverse effects of elevated levels of endogenous or exogenous GCs, on organs involved in the regulation of glucose metabolism.

Our work has contributed to the identification of GSK3 as a viable target to mitigate GC deleterious effects in pancreatic $\beta$-cells. These novel findings indicate that in susceptible individuals with prediabetic condition, GC therapy may become significantly safer, by combining GCs with GSK3 inhibitors as an adjunct treatment, which interestingly has been shown to have powerfull anti-inflammatory effects in chronic inflammatory diseases [46, 57-60].

\section{MATERIALS AND METHODS}

\section{Animals}

Animals used in this study were male Wistar rats from our local colony. Animal housing and breeding and relevant procedures were conducted in accordance with the European Community Council directives (2010/63/UE) and approved by the institutional Animal Care and Use Ethical Committee of the Paris-Diderot University (Agreement B-75-13-17). Animal were housed in controlled environment (temperature $=20 \pm 1^{\circ} \mathrm{C}$; humidity $=60 \%$ ) with food and water ad libitum on $12 \mathrm{~h}$ light/dark cycle. After weaning, animals were fed with a standard chow diet (diet D113, SAFE, Augy, France).

\section{Rat islet isolation}

Rat islets were isolated from 10-12 weeks old male Wistar rats. Pancreatic islets were isolated by Liberase (Roche, Boulogne Billancourt, France, ref. $05401020001)$ digestion $\left(37^{\circ} \mathrm{C}, 15 \mathrm{~min}\right)$ and Histopaque ${ }^{\circledR} 1077$ (Sigma, Saint Quentin Fallavie, France, ref. 10771) gradient purification as previously described [61]. Islets were hand-picked under a stereomicroscope and divided into different batches.

\section{Islet and $\beta$-cell culture and treatments}

Batches of 150 freshly isolated islets were stabilized in RPMI 1640 + Glutamax medium (Gibco, Illkirch, France, ref. 61870036) with 10\% Fetal Calf Serum (FCS) (Eurobio, Les Ulis, France, ref. CVFSVF00-01), 1\% Penicillin-Streptomycin (Sigma, Saint Quentin Fallavie, France, ref. P4333), 1\% Hepes (Sigma, Saint Quentin Fallavie, France, ref. H0887), 1\% Sodium pyruvate (Sigma, Saint Quentin Fallavie, France, ref. S8636) during $36 \mathrm{~h}$. Islets were then pre-treated or not with $10 \mathrm{mM} \mathrm{LiCl}$ (Sigma, Saint Quentin Fallavie, France, ref. L7026) or with 20 MM SB216763 (Sigma, Saint Quentin Fallavie, France, ref. S3442) during $3 \mathrm{~h}$. Next, Dexamethasone (Sigma, Saint Quentin Fallavie, France, ref. D4602) at the concentration of $100 \mathrm{nM}$ was added or not to the medium and incubated for $24 \mathrm{~h}$. Islets were then processed for histology, insulin secretion measurement, real-time PCR or Western blot analysis.

Rat insulinoma INS-1 832/13 cells were grown in RPMI 1640 + Glutamax medium with 10\% Fetal Calf Serum, 1\% Penicillin-Streptomycin, 1\% Hepes, $1 \%$ Sodium Pyruvate, 50 MM B-mercaptoethanol (Gibco, Illkirch, France, ref. $3150-010)$. INS-1 832/13 cells were treated or not with $20 \mu$ M SB216763 and $100 \mathrm{nM}$ Dexamethasone according to the protocol described above. For immunofluorescence analysis and cellular fractionation, cells were subjected to SB216763 and Dexamethasone treatment during only $3 \mathrm{~h}$, in FCS-free medium.

\section{Human islets}

Human islets were isolated from four brain-dead non-diabetic donors with prior consent for research use at Saint-Louis Hospital (Paris, France) according to a modified version of the automated method $[62,63]$. The isolated islets were washed and cultured in CMRL 1066 medium (Sigma, Saint Quentin Fallavie, France, ref. CR1136), which contained $5.6 \mathrm{mM}$ glucose, $25 \mathrm{mM}$ Hepes, $2 \mathrm{mM}$ glutamine, $100 \mathrm{U} / \mathrm{mL}$ penicillin, $100 \mathrm{mg} / \mathrm{mL}$ streptomycin, and $10 \%$ fetal calf serum. After reception, human islets were cultured for an additional $48 \mathrm{~h}$ for recovery in our laboratory. Then, they were treated or not with $10 \mathrm{mM} \mathrm{LiCl}$ during $24 \mathrm{~h}$, and processed for real-time PCR.

\section{Cell transfection}

INS-1 832/13 cells have been transfected with $5 \mathrm{nM}$ siRNA, using the protocol Fast-Forward Transfection with HiPerFect Transfection Reagent (Qiagen, Courtaboeuf, France) following the manufacturer instructions, in antibiotics and serum-free OPTI-MEM + Glutamax medium (Gibco, Illkirch, France, ref. 51985-026), on $5 \times 10^{5}$ cells. Following transfection, cells were cultured in OPTI-MEM supplemented with 10\% Fetal Calf Serum, 1\% Penicillin-Streptomycin, $1 \%$ Hepes, $1 \%$ Sodium pyruvate, $50 \mu \mathrm{M}$ $\beta$-mercaptoethanol. The following siRNAs have been used: Control siRNA (Qiagen, Germantown, Maryland, USA, ref. 1022076), siGSK3ß-Flexitude_3 (Qiagen, Germantown, Maryland, USA, ref. SI03056879), siGSK3a-Flexitube_2 (Qiagen, Germantown, Mariland, USA, ref. SI03080105). siRNAs target sequences are provided in Table 1. 
A

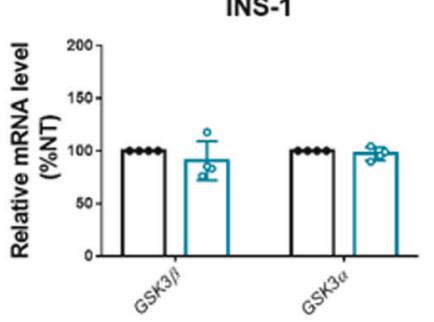

C

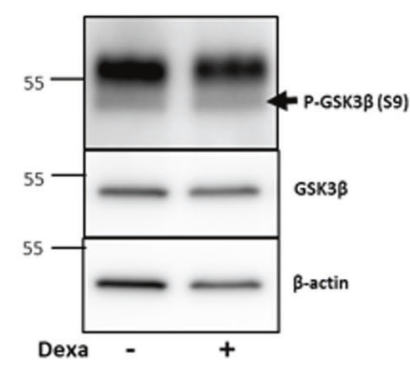

D

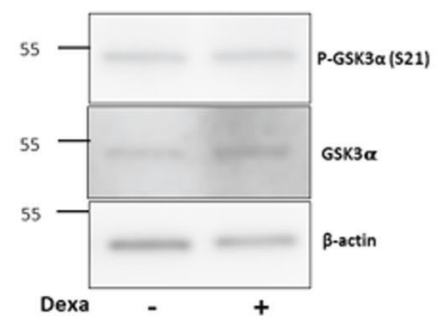

$\mathbf{E}$

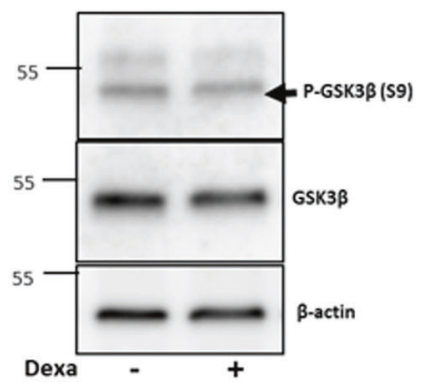

$\mathbf{F}$

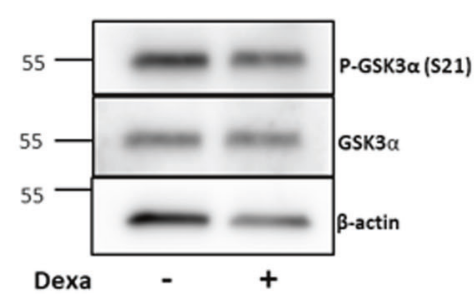

B

$$
\text { - } \mathrm{NT}
$$

- Dexa

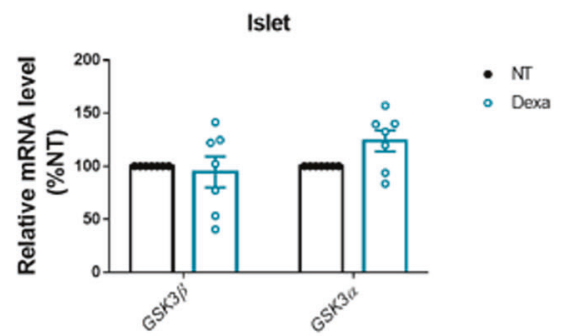

\section{INS-1}
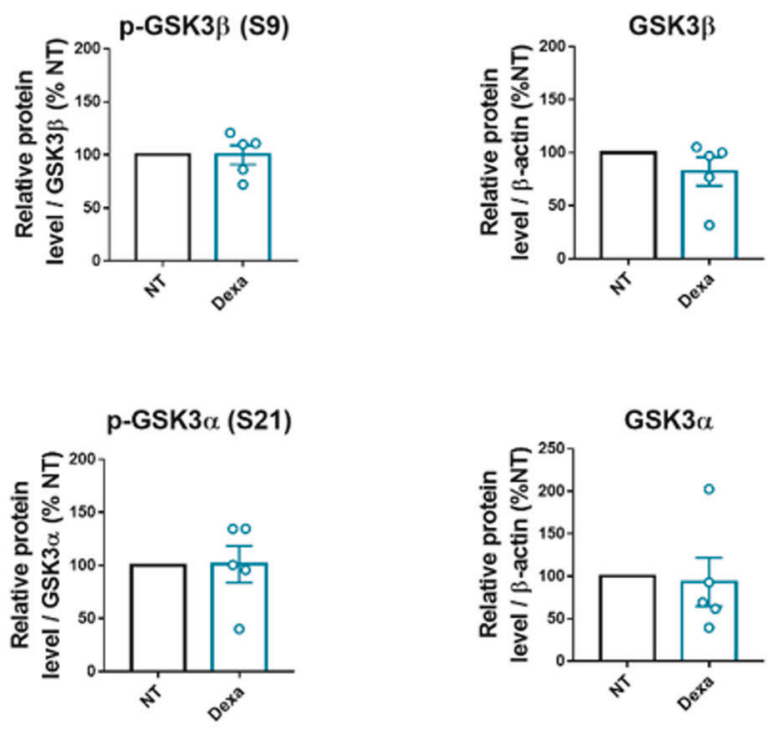

ISLET
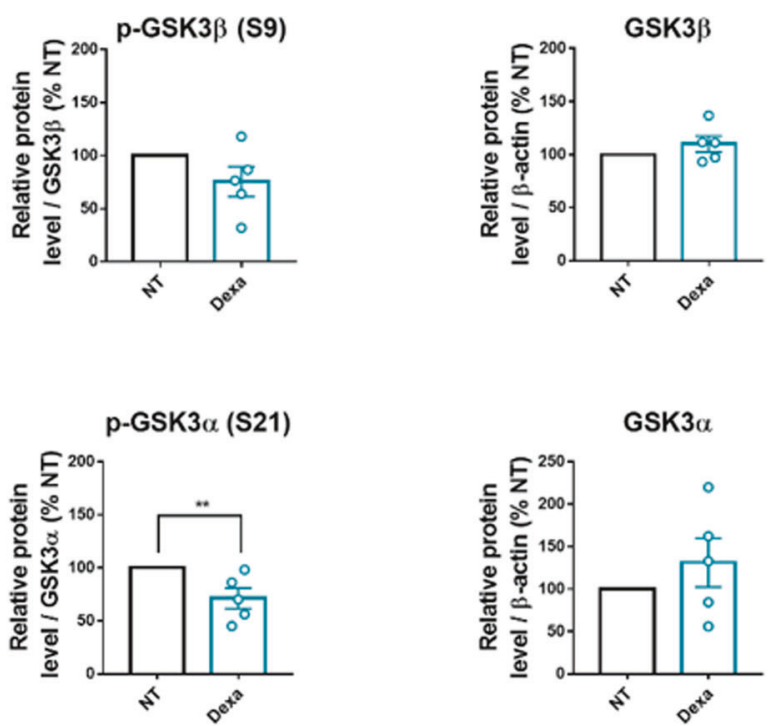

\section{Lentiviral production, titration and cell infection}

We used two GSK3 $\beta$ shRNA constructs (Origene, Herford, Germany, ref TL711670\#A and TL711670\#C) and a scrambled shRNA (Origene, Herford, Germany, ref TR30021). The cassettes were inserted in a lentiviral GFP vector. shRNA sequences are reported in Table 2. Lentiviral particles were produced by transient transfection of HEK293T cells (ATCC ${ }^{\circledR}$ CRL-3216 ${ }^{\mathrm{TM}}$ ) using calcium phosphate with the packaging plasmids pMD2.G (Addgene ref 12259) and psPAX2 (Addgene ref 12260) to form the viral particles, together with a rat shRNA-GFP lentiviral construct.

The culture medium was collected $48 \mathrm{~h}$ after transfection of HEK293T and filtered through $0.45 \mu \mathrm{m}$ pores. Lentiviral particles were concentrated by ultracentrifugation at 25,000 r.p.m. for $2 \mathrm{~h}$ and then resuspended in 
Fig. 3 Dexa does not change GSK3 $\alpha$ and GSK3 $\beta$ expression in INS-1 832/13 and in rat islets neither their activity. A Relative mRNA levels of Gsk3a and Gsk3 $\beta$, measured by qPCR $(n=4)$ in INS-1 832/13, after $24 \mathrm{~h}$ incubation with or without Dexamethasone (Dexa). Results are expressed as percentage of NT condition for each independent experiment. B Relative mRNA levels of GSK3a and GSK3 $\beta$, measured by qPCR $(n=7)$, in islets, after $24 \mathrm{~h}$ incubation with or without Dexamethasone (Dexa). Results are expressed as percentage of NT condition for each independent experiment. Cyclophilin A is used as housekeeping gene in A and B. C Representative Western Blot (left) and quantification (right) of P-GSK3 $\beta$ (S9) and GSK3 $\beta$ protein levels in INS-1 $832 / 13$ cells after $24 \mathrm{~h}$ incubation with or without Dexamethasone (Dexa) ( $n=5$ ). $\beta$-actin is used as loading control. Results are expressed as percentage of NT for each independent experiment. Black arrow shows the band corresponding to P-GSK3 $\beta$ (S9). D Representative Western Blot (left) and quantification (right) of P-GSK3 $\alpha$ (S21) and GSK3 $\alpha$ protein levels in INS-1 832/13 cells after $24 \mathrm{~h}$ incubation with or without Dexamethasone (Dexa) $(n=5)$. $\beta$-actin is used as loading control. Results are expressed as percentage of NT for each independent experiment. E Representative Western Blot (left) and quantification (right) of P-GSK3 $\beta$ (S9) and GSK3 $\beta$ protein levels in rat islets after $24 \mathrm{~h}$ incubation with or without Dexamethasone (Dexa) $(n=5)$. $\beta$-actin is used as loading control. Results are expressed as percentage of NT for each independent experiment. Black arrow shows the band corresponding to P-GSK3 $\beta$ (S9). F Representative Western Blot (left) and quantification (right) of P-GSK3 $\alpha$ (S21) and GSK3 $\alpha$ levels in rat islets after $24 \mathrm{~h}$ incubation with or without Dexamethasone (Dexa) $(n=5)$. $\beta$-actin is used as loading control. Results are expressed as percentage of NT for each independent experiment. Results are shown as means \pm S.E.M. $n$ represents the number of independent experiments. ${ }^{* *} p<0.01$.
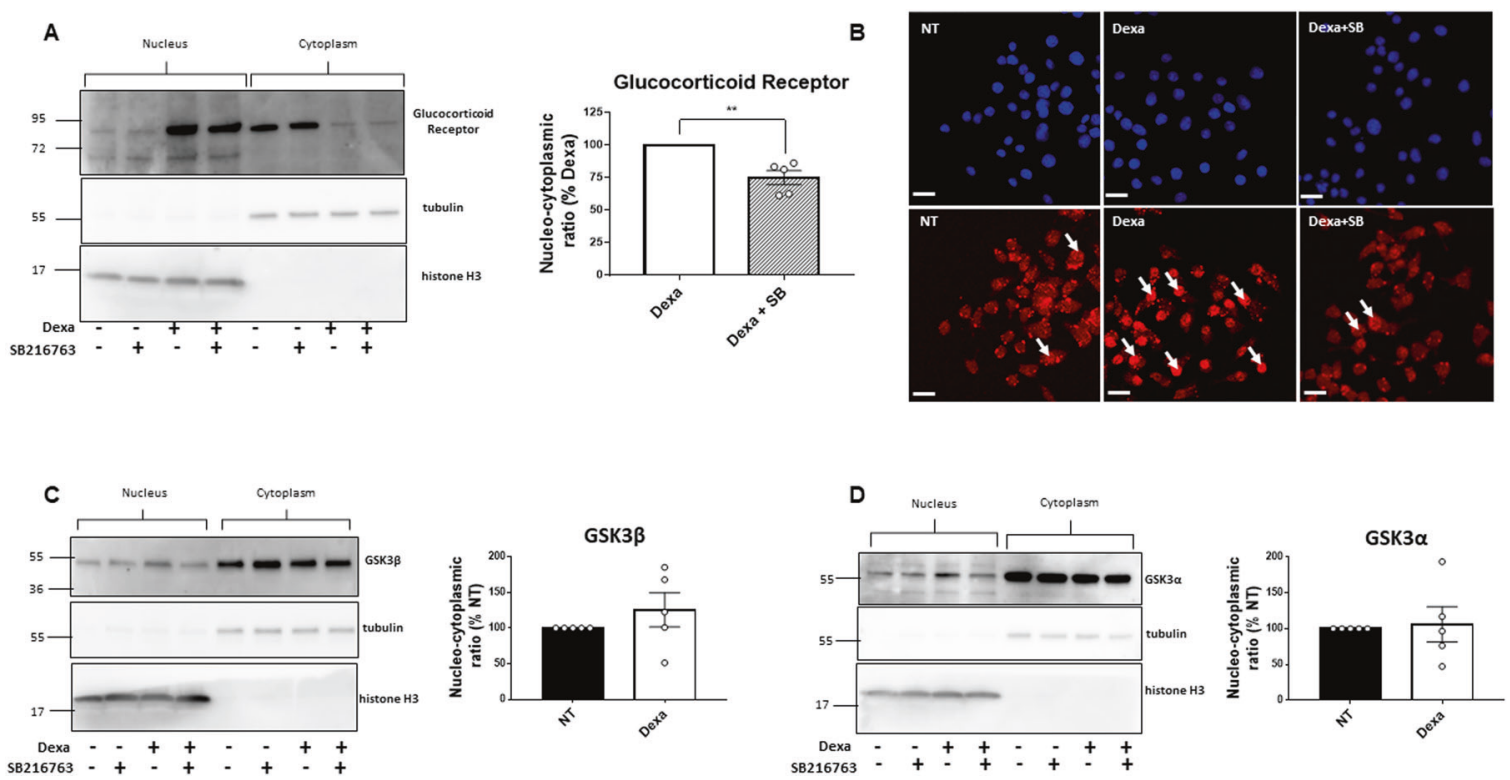

Fig. 4 Treatment with SB216763 reduces the nuclear GR localization following Dexa treatment. A Representative Western Blot (left) and quantification (right) of nuclear and cytoplasmic GR protein levels in INS-1 832/13 after $3 \mathrm{~h}$ incubation with or without Dexamethasone (Dexa) and with or without SB216763 (SB) $(n=5)$. Tubulin is used as the marker of the cytoplasmic fraction. Histone H3 is used as the marker of the nuclear fraction. Results are expressed as the percentage of Dexa condition for each independent experiment. B Representative images showing DAPI (upper panel) and GR staining (lower panel) in INS-1 832/13 after $3 \mathrm{~h}$ incubation with or without Dexamethasone (Dexa) and $3 \mathrm{~h}$ with or without SB216763 (SB). White arrows show examples of nuclear staining of the GR. Scale bar: $20 \mu \mathrm{m}$. C Representative Western Blot (left) and quantification (right) of nuclear and cytoplasmic GSK3 $\beta$ protein level in INS-1 832/13 after $3 \mathrm{~h}$ incubation with or without Dexamethasone (Dexa) and with or without SB216763 (SB) $(n=5)$. Tubulin is used as the marker of the cytoplasmic fraction. Histone H3 is used as the marker of the nuclear fraction. Results are expressed as the percentage of NT condition for each independent experiment. D Representative Western Blot (left) and quantification (right) of nuclear and cytoplasmic GSK3 $\alpha$ levels in INS-1 832/13 after $3 \mathrm{~h}$ incubation with or without Dexamethasone (Dexa) and with or without SB216763 (SB) $(n=5)$. Tubulin is used as the marker of the cytoplasmic fraction. Histone $\mathrm{H} 3$ is used as the marker of the nuclear fraction. Results are expressed as the percentage of NT condition for each independent experiment. Results are shown as means \pm S.E.M. $n$ represents the number of independent experiments. ${ }^{* *} p<0.01$.

$200 \mu \mathrm{L}$ PBS. For each construct, the lentiviral titer was determined by infection of HEK293T cells and FACS analysis.

$2 \times 10^{5}$ INS-1 832/13 cells were infected with lentiviral particles containing scrambled shRNA-GFP, GSK3ß.1 shRNA-GFP, or GSK3ß.2 shRNA-GFP construct ( $\mathrm{MOI}$ of 10). Infected cells were treated or not with $100 \mathrm{nM}$ Dexamethasone during $24 \mathrm{~h}$ and processed for real-time PCR, western blotting or flow cytometry analysis.

\section{Flow cytometry}

INS-1 832/13 cell death has been assessed by 7-AAD (BD Biosciences, Le Pont de Claix, France, ref. 28025013) incorporation or by Annexin V-FITC incorporation (Biolegend, San Diego, California, USA, ref. 640922) assay according to the manufacturer's instructions and quantified on a FACS ARIA II flow cytometer (BD Biosciences, Le Pont de Claix, France).

\section{Real-time PCR}

Total RNA was extracted from rat islets, human islets or INS-1 832/13 cells using the RNeasy mini kit (Qiagen, Courtaboeuf, France, ref. 74104). cDNA of each RNA sample was synthesized with Moloney murine leukemia virus (M-MLV) reverse transcriptase kit (Invitrogen, Illkirch, France, ref. 28025013). Real-time quantitative PCR amplification reactions were carried out in a LightCycler 480 detection system (Roche, Boulogne-Billancourt, France) using the LightCycler SYBR Green 480 kit (Roche, BoulogneBillancourt, France, ref. 04887352001). The primer sets were designed using OLIGO7 and are described in Table 3. All reactions were run in duplicate. Cyclophilin A were chosed as housekeeping gene for rat and TBP were chosed as housekeeping gene for human islets, as described in [44]. The PCR program was set as follows: $95^{\circ} \mathrm{C} 10 \mathrm{~min}$, followed by 40 cycles at $95^{\circ} \mathrm{C} 10 \mathrm{~s}, 60^{\circ} \mathrm{C} 10 \mathrm{~s}$ and $72^{\circ} \mathrm{C}$ for $10 \mathrm{~s}$. 
A Glucorticoid Receptor

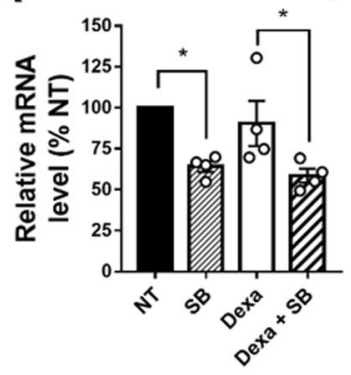

C

C Glucorticoid Receptor

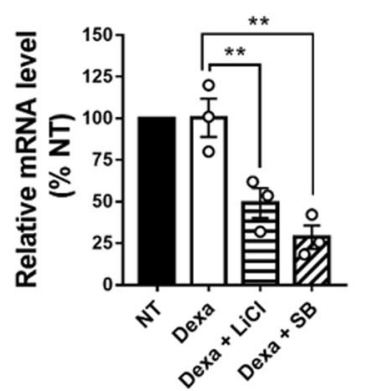

INS-1

B Glucocorticoid Receptor
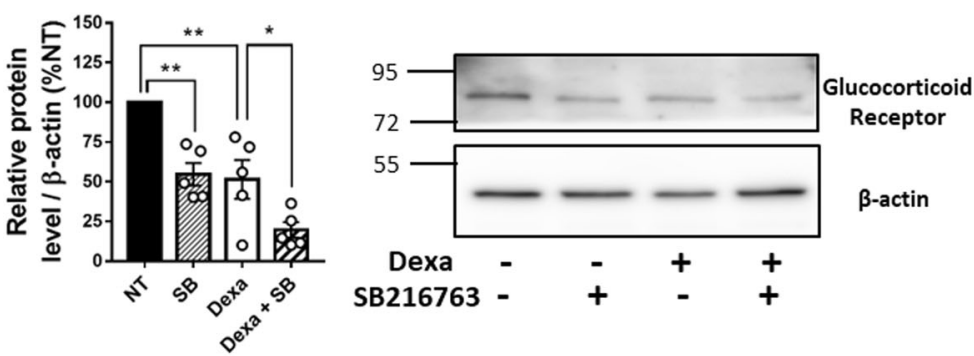

55

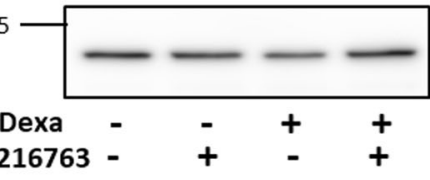

$\beta$-actin

\section{RAT ISLET}

D

\section{Glucocorticoid Receptor}
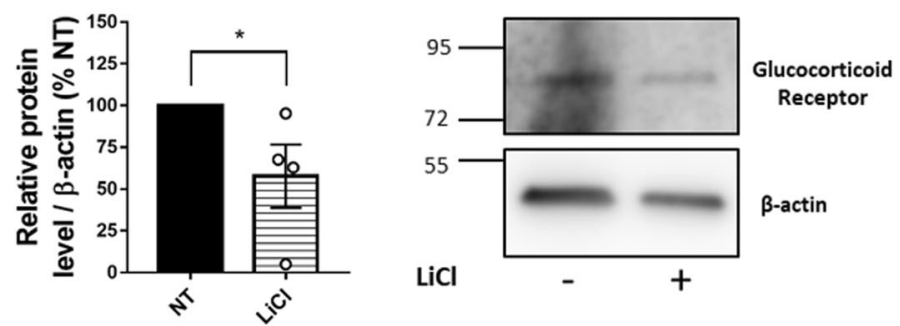

HUMAN ISLET

E

\section{Glucorticoid Receptor}

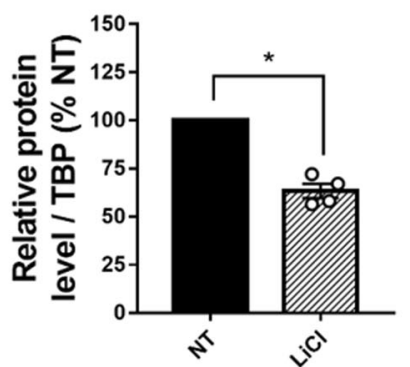

Fig. 5 Treatment with LiCl or SB216763 reduces the GR expression in INS-1 832/13 cells as well as in rat and human islets. A Relative mRNA level of GR, measured by qPCR $(n=4)$, in INS-1 832/13, after $24 \mathrm{~h}$ treatment with or without Dexamethasone (Dexa) and $27 \mathrm{~h}$ with or without SB216763 (SB). Results are expressed as percentage of NT condition for each independent experiment. B Representative Western Blot (right) and quantification (left) of GR protein level in INS-1 832/13 after $24 \mathrm{~h}$ incubation with or without Dexamethasone (Dexa) and $27 \mathrm{~h}$ incubation with or without SB216763 (SB) $(n=5)$. $\beta$-actin is used as loading control. Results are expressed as percentage of NT condition for each independent experiment. C Relative mRNA level of $G R$, measured by qPCR $(n=3)$ in rat islets, after $24 \mathrm{~h}$ incubation with or without Dexamethasone (Dexa) and $27 \mathrm{~h}$ incubation with or without LiCl or SB216763. Results are expressed as percentage of NT condition for each independent experiment. D Representative Western Blot (right) and quantification (left) of GR protein level in rat islets after $24 \mathrm{~h}$ incubation with or without Dexamethasone (Dexa) and $27 \mathrm{~h}$ incubation with or without $\mathrm{LiCl}(n=4)$. $\beta$-actin is used as loading control. Results are expressed as percentage of NT condition for each independent experiment. E Relative mRNA level of human $G R$, measured by qPCR ( $n=4$ ), in human islets, after $24 \mathrm{~h}$ treatment with or without $\mathrm{LiCl}$. Results are expressed as percentage of NT condition for each independent experiment. Cyclophilin A is used as housekeeping gene in figure $\mathbf{A}$ and $\mathbf{C}$. TBP is used as housekeeping gene in figure $\mathbf{E}$.

\section{Cell death detection}

For immunohistochemical studies, following the treatments described above, islets from each group were hand-picked, fixed in aqueous Bouin's solution for $1 \mathrm{~h}$, embedded in agarose (Sigma, Saint Quentin Fallavie, France, ref. A6013) and then in paraplast (Leica, Nanterre, France, ref. 39602004). Blocs were serially sectioned ( $5 \mu \mathrm{m}$ thickness). Cell death was assessed by the TUNEL apoptosis detection kit (Sigma, Saint Quentin Fallavie, France, ref. S7101) on islet sections, according to the manufacture's protocol, with the modification of TdT enzyme concentration which was further diluted $(1 / 10)$ to adapt to our experimental conditions. Quantification was made using a computer-assisted image analysis system Histolab 5.14 software (Microvision Instruments, Lisses, France). At least 20 islets were counted per experimental condition.

\section{Measurement of glucose-induced insulin secretion}

Freshly isolated Wistar islets were stabilized in RPMI1640 + Glutamax complete medium during $36 \mathrm{~h}$, then transferred into a RPMI 1640 medium 
A
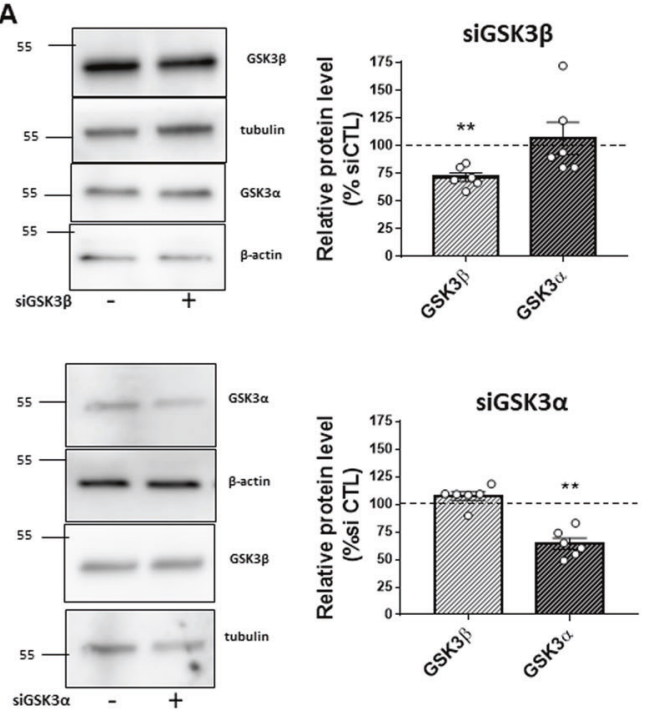

C


D
B

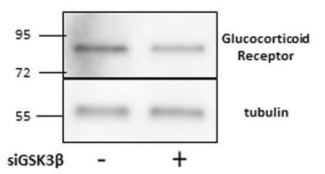

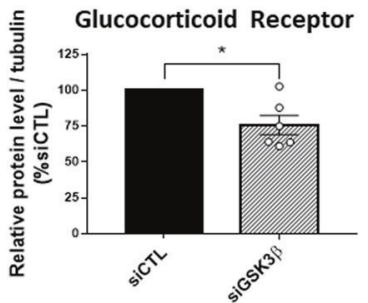

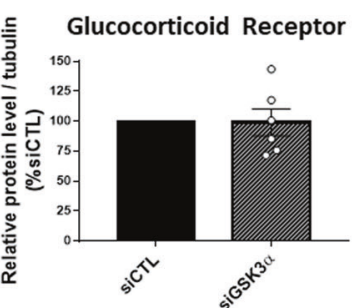

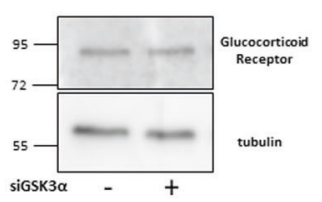

E
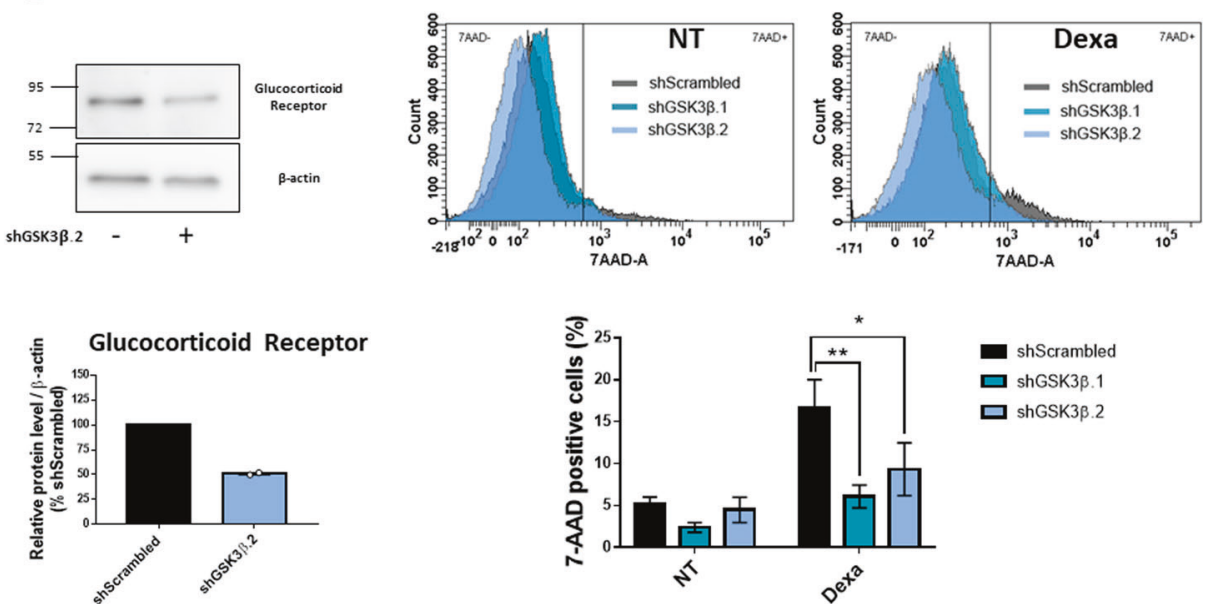

Fig. 6 GSK3 $\beta$ knock-down is sufficient to decrease GR expression and GC-induced $\boldsymbol{\beta}$-cell death. A Representative Western Blot (left) and quantification (right) of GSK3 $\beta$ and GSK3 $\alpha$ levels in INS-1 832/13 after $24 \mathrm{~h}$ incubation with GSK3 $\beta$ siRNA (upper panel, $n=6$ ) or with GSK3 $\alpha$ siRNA (lower panel, $n=6$ ). $\beta$-actin is used as loading control for GSK3 $\alpha$ and tubulin is used as loading control for GSK3 $\beta$. Results are expressed as percentage of siCTL condition, represented by dashed line, for each independent experiment. B Representative Western Blot (left) and quantification (right) of GR protein level in INS-1 832/13 after $24 \mathrm{~h}$ incubation with GSK3 $\beta$ siRNA (upper panel, $n=6$ ), or with GSK3 $\alpha$ siRNA (lower panel, $n=6$ ). Tubulin is used as loading control. Results are expressed as percentage of siCTL condition for each independent experiment. C Relative mRNA level of GSK3 $\beta$ (upper panel) and GSK3 $\alpha$ (lower panel), measured by qPCR, in INS-1 832/13, after infection with lentivirus coding for scrambled shRNA (shScr), GSK3 $\beta .1$ shRNA (shGSK3 $\beta .1$ ) or GSK3 $\beta .2$ shRNA (shGSK3 $\beta .2)(n=3)$ ). Results are expressed as percentage of scrambled shRNA condition, represented by dashed line, for each independent experiment. D Representative Western-blot (upper panel) and quantification (lower panel) of GR protein level in GFP sorted INS-1 832/13 after infection with lentivirus coding for scrambled shRNA or GSK3 3.2 shRNA $(n=2)$. $\beta$-actin is used as loading control. Results are expressed as percentage of scrambled shRNA condition for each independent experiment. E Cell death reported by 7-AAD incorporation measured by flow cytometry, and quantification ( $n$ $=5)$, after infection of INS-1 832/13 cells with lentivirus coding for scrambled shRNA, GSK3 $\beta .1$ shRNA or GSK3 $\beta .2$ shRNA, and $24 \mathrm{~h}$ after incubation with (right panel) or without Dexamethasone (Dexa) (left panel). Cyclophilin A is used as housekeeping gene in figure C. Results are shown as means \pm S.E.M. $n$ represents the number of independent experiments. ${ }^{*} p<0.05 ;{ }^{* *} p<0.01$.

Table 1. List of rat siRNAs sequences.

\begin{tabular}{|c|c|}
\hline Gene targeted & Sequence targeted \\
\hline siCTL duplex & 5'-AATTCTCCGAACGTGTCACGT-3' \\
\hline $\operatorname{siGSK3} \alpha$ & 5'-ACGTCGATTCACACCATCCAA-3' \\
\hline siGSK3 $\beta$ & 5'-CCCAAATTATACAGAATTCAA-3' \\
\hline
\end{tabular}

containing or not $10 \mathrm{mM} \mathrm{LiCl}$ or $20 \mu \mathrm{M} \mathrm{SB} 216763$ for pre-treatment. After $3 \mathrm{~h}$ pre-treatment, $100 \mathrm{nM}$ Dexamethasone was added or not to the media for $24 \mathrm{~h}$. Following $24 \mathrm{~h}$ incubation, batches of 10 islets from each group were pre-incubated for $1 \mathrm{~h}$ in a Krebs- Ringer/bicarbonate/Hepes buffer
Table 2. List of rat shRNA sequences.

\begin{tabular}{ll}
\hline shRNA & Sequence \\
\hline shScrambled & 5'-GCACTACCAGAGCTAACTCAGATAGTACT-3' $^{\prime}$ \\
\hline shGSK3 $\beta .1$ & $5^{\prime}$-ACCGTGGACAGACCAATAACGCCGCTTCT-3' \\
\hline shGSK3 $\beta .2$ & $5^{\prime}$-AGCCTCAGATACTAATGCTGGAGACCGTG-3' \\
\hline
\end{tabular}

$(115 \mathrm{mM} \mathrm{NaCl}, 5 \mathrm{mM} \mathrm{KCl}, 24 \mathrm{mM} \mathrm{NaHCO} 3,1 \mathrm{mM} \mathrm{CaCl}, 1 \mathrm{mM} \mathrm{MgCl}$ ) containing $0.2 \%$ fatty-acid-free BSA (Roche, Boulogne-Billancourt, France, ref. 10775835001) and $2.8 \mathrm{mM}$ glucose, followed by $1 \mathrm{~h}$ incubation in 2.8 or $16.7 \mathrm{mM}$ glucose, to measure glucose-induced insulin secretion. Insulin 
Table 3. List of primers.

\begin{tabular}{|c|c|c|}
\hline Gene & Forward & Reverse \\
\hline$B C l-2$ & 5'-CGGTGGTGGAGGAACTCTTCA-3' & 5'- CTGGGGCCATATAGTTCCACAA- $3^{\prime}$ \\
\hline Bim & 5'- AAGTCAACACAAACCCCAAGTCC-3' & 5'- CCTCCTCGTGTAAGTCTCATTGAAC-3' \\
\hline Chop & 5'- CAAGCACCTCCCAAAGCCCTCG-3' & 5'- CCTTCTCCTTCATGCGCTGT-3' \\
\hline Cyclophilin A & $5^{\prime}-$ AACCCACCGTGTTCTTC-3' & 5'- TGCCTTCTTTCACCTTCCC-3' \\
\hline Glucocorticoid Receptor & 5'-TTTCCCAAAACTCACTCGGAT-3' & 5'-TACAATTTCACACTGCCTCCGTT-3' \\
\hline Gsk3a & 5'-GGCCCTGCTACCCTCACCTCG-3' & 5'- CCCTTTCCAGCCCACTTGAGCCT-3' \\
\hline Kv1.5 & 5'-ACTTCGCAGAGGCAGACAATCA-3' & 5'-GGTTGCCTTGTTCTTCCTTCAG-3' \\
\hline Nox4 & 5'-AGAAAGATTCCGAGATTTACTACTGC-3' & 5'- AAACGGAGTGACCCCAATGC-3' \\
\hline Sgk1 & 5'-AAACCTATTGAAACGGTCTTGC-3' & 5'-ACGGCTCTGACTGACAAC-3' \\
\hline Sod1 & 5'- TGGTCCACGAGAAACAAGATG-3' & 5'- AATCCCAATCACACCACAAGCCAA- $3^{\prime}$ \\
\hline Sod2 & 5'- GGCCAAGGGAGATGTTACAA-3' & 5'- GACCCAAAGTCACGCTTG-3' \\
\hline
\end{tabular}

released in the supernatant was measured by ELISA (Alpco Diagnostics, Salem, Massachusetts, USA, ref. 80-INSRTU-E01), and normalized to islet DNA content.

\section{Cellular fractionation}

INS-1 $832 / 13$ cells were cultured for $3 \mathrm{~h}$ in serum-free RPMI1640 + Glutamax with or without SB216763 $20 \mu \mathrm{M}$, and with or without Dexamethasone $100 \mathrm{nM}$. Cells were resuspended in SF buffer $(250 \mathrm{mM}$ Sucrose, $20 \mathrm{mM}$ HEPES, $10 \mathrm{mM} \mathrm{KCl}, 1,5 \mathrm{mM} \mathrm{MgCl} 2,1 \mathrm{mM}$ EDTA, $1 \mathrm{mM}$ EGTA) supplemented extemporaneously with $1 \mathrm{mM}$ DTT, 4\% Protease Inhibitor Cocktail (Sigma, Saint Quentin Fallavie, France, ref. P5726) and $5 \mathrm{mM}$ spermine (Sigma, Saint Quentin Fallavie, France, ref. S3256) and spermidine (Sigma, Saint Quentin Fallavie, France, ref. S2626). After 30 min agitation in SF, cells were centrifuged at $720 \mathrm{~g}$ for $10 \mathrm{~min}$ to separate nonlysed cells, nuclei and cytoplasm. The pellet containing nuclei were washed in $\mathrm{SF}$ and resuspended in NL buffer $(50 \mathrm{mM}$ Tris $\mathrm{HCl} \mathrm{pH}=8,150 \mathrm{mM} \mathrm{NaCl}$, $1 \%$ NP-40, $0.5 \%$ sodium deoxycholate, $0.1 \%$ SDS, $4 \%$ Protease Cocktail Inhibitor). The supernatant containing cytoplasm were washed to remove traces of nuclei and were ultracentrifugated at $100000 \mathrm{~g}$ for $1 \mathrm{~h}$ to separate cytoplasm and membrane fractions. Western blot analysis were performed in nuclear and cytoplasmic fractions.

\section{Western blot analysis}

Western blot analysis were performed on INS-1 832/13 or rat islets, lysed in RIPA buffer (Cell Signaling, Saint-Cyr, France, ref. 9806) with $4 \%$ protease inhibitor cocktail PIC, PIC2, PIC3 (Sigma, Saint Quentin Fallavie, France, ref. P5726). Fifteen $\mu \mathrm{g}$ protein were subjected to SDS-PAGE and transferred on a PVDF membrane (Sigma, Saint Quentin Fallavie, France, ref. IPVH09120). After blocking with $5 \%$ milk or $5 \%$ fatty acid free BSA, the membrane was incubated with corresponding primary antibody: anti-Bim (Cell Signaling, Saint-Cyr, France, ref. 2819), anti-Bcl-2 (eBiosciences, Illkirch, France, ref. 146992-82), anti-pSer9GSK3 $\beta$ (Cell Signaling, Saint-Cyr, France, ref. 5558), antiGSK3 $\beta$ (Cell Signaling, Saint-Cyr, France, ref. 9315), anti-pSer21GSK3a (Cell Signaling, Saint-Cyr, France, ref. 9316), anti-GSK3a (Cell Signaling, Saint-Cyr, France, ref. 9338), anti-GR (Cell Signaling, Saint-Cyr, France, ref. 12041), anti$\beta$-actin (Sigma, Saint Quentin Fallavie, France, ref. 2709), anti-Histone H3 (Cell Signaling, Saint-Cyr, France, ref. 4499), or anti- $\alpha / \beta$-tubulin (Cell Signaling, SaintCyr, France, ref. 2148). The addition of appropriate horseradish peroxidaseconjugated secondary antibody (Jackson Labs, Las Vegas, USA) allowed to visualize the reaction using a chimioluminescence system with ECL Prime (Amersham, Les Ulis, France, ref 29018903). Membranes were then stripped using Re-Blot solution (Millipore, Molsheim, France, ref 2504) and then reprobed with appropriate antibody. The results were analyzed and quantified by scanning densitometry using $\mathrm{FIJI}^{\circledR}$.

\section{Immunofluorescence}

Following $3 \mathrm{~h}$ incubation with the different treatments described above, INS-1 $832 / 13$ cells were fixed in a solution of $4 \%$ formaldehyde (Sigma, France, ref. F8775). Then, cells were permeabilized with Triton $0.2 \%$ for
$20 \mathrm{~min}$, and incubated with $10 \%$ goat serum for $1 \mathrm{~h}$. Cells were then incubated with anti-GR antibody overnight at $4{ }^{\circ} \mathrm{C}$ (Cell Signaling, France, ref. 12041) followed by incubation with anti-rabbit fluorescent secondary antibody for $1 \mathrm{~h}$ at room temperature. Finally, cells were covered with mounting medium containing DAPI. Images were acquired using confocal microscopy Zeiss LSM 700.

\section{Data and statistical analysis}

Results are expressed as means \pm S.E.M. In the legends, " $n$ " is the number of independent experiments performed. When it was possible, the experimental groups were blinded to the investigator that performed the quantification/analyses. For each data set, the outliers were identified by the appropriate statistical test. The statistical significances between means were assessed by Mann-Whitney test (two groups), or by One-Way or Two-Way ANOVA followed by Tukey's or Dunnett's post-hoc analysis when more than two conditions were compared, using Graph-Pad Prism 7 software. $P$-values are indicated in graph as followed: ${ }^{*} p<0.05$; ${ }^{* *} p<$ $0.01 ;{ }^{* * *} p<0.001 ;{ }^{* * * *} p<0.0001$.

\section{DATA AVAILABILITY}

The raw data supporting the conclusions of this manuscript will be made available by the authors, without undue reservation, to any qualified researcher.

\section{REFERENCES}

1. Gjerstad JK, Lightman SL, Spiga F. Role of glucocorticoid negative feedback in the regulation of HPA axis pulsatility. Stress 2018;21:403-16.

2. De Bosscher K, Haegeman G, Elewaut D. Targeting inflammation using selective glucocorticoid receptor modulators. Curr Opin Pharm. 2010;10:497-504.

3. Zeiser R, Blazar BR. Acute graft-versus-host disease - biologic process, prevention, and therapy. N. Engl J Med. 2017;377:2167-79.

4. Thiele K, Buttgereit F, Huscher D, Zink A, German Collaborative Arthritis Centres. Current use of glucocorticoids in patients with rheumatoid arthritis in Germany. Arthritis Rheum. 2005;53:740-7.

5. Nair P, Wenzel S, Rabe KF, Bourdin A, Lugogo NL, Kuna P, et al. ZONDA Trial Investigators. Oral glucocorticoid-sparing effect of benralizumab in severe asthma. N. Engl J Med. 2017;376:2448-58.

6. Goodin DS. Glucocorticoid treatment of multiple sclerosis. Handb Clin Neurol 2014;122:455-64.

7. Pratt WB, Morishima $Y$, Murphy M, Harrell M. Chaperoning of glucocorticoid receptors. Handb Exp Pharm. 2006;172:111-38.

8. Beck IM, Vanden Berghe W, Vermeulen L, Yamamoto KR, Haegeman G, De Bosscher K. Crosstalk in inflammation: the interplay of glucocorticoid receptor-based mechanisms and kinases and phosphatases. Endocr Rev. 2009;30:830-82.

9. Compston J. Glucocorticoid-induced osteoporosis: an update. Endocrine 2018;61:7-16

10. Schakman O, Kalista S, Barbé $C$, Loumaye A, Thissen JP. Glucocorticoid-induced skeletal muscle atrophy. Int J Biochem Cell Biol. 2013;45:2163-72. 
11. Bauerle KT, Harris C. Glucocorticoids and diabetes. Mol Med. 2016;113:378-83.

12. Barbot M, Ceccato F, Scaroni C. Diabetes mellitus secondary to Cushing's disease. Front Endocrinol (Lausanne). 2018;9:284.

13. Hjelmesaeth J, Hartmann A, Kofstad J, Egeland T, Stenstrøm J, Fauchald P. Tapering off prednisolone and cyclosporin the first year after renal transplantation: the effect on glucose tolerance. Nephrol Dial Transpl. 2001;16:829-35.

14. Gulliford MC, Charlton J, Latinovic R. Risk of diabetes associated with prescribed glucocorticoids in a large population. Diabetes Care. 2006;29:2728-9.

15. van Raalte $\mathrm{DH}$, Nofrate V, Bunck MC, van lersel T, Elassaiss Schaap J, Nässander UK, et al. Acute and 2-week exposure to prednisolone impair different aspects of beta-cell function in healthy men. Eur J Endocrinol. 2010;162:729-35.

16. Gesina E, Blondeau B, Milet A, Le Nin I, Duchene B, Czernichow P, et al. Glucocorticoid signalling affects pancreatic development through both direct and indirect effects. Diabetologia 2006;49:2939-47.

17. Lambillotte C, Gilon P, Henquin JC. Direct glucocorticoid inhibition of insulin secretion. An in vitro study of dexamethasone effects in mouse islets. J Clin Invest. 1997;99:414-23.

18. Davani B, Portwood N, Bryzgalova G, Reimer MK, Heiden T, Ostenson CG, et al. Aged transgenic mice with increased glucocorticoid sensitivity in pancreatic beta-cells develop diabetes. Diabetes 2004;53:S51-9. Suppl 1

19. Ranta F, Avram D, Berchtold S, Düfer M, Drews G, Lang F, et al. Dexamethasone induces cell death in insulin-secreting cells, an effect reversed by exendin-4. Diabetes 2006;55:1380-90.

20. Hurel SJ, Rochford JJ, Borthwick AC, Wells AM, Vandenheede JR, Turnbull DM, et al. Insulin action in cultured human myoblasts: contribution of different signalling pathways to regulation of glycogen synthesis. Biochem J. 1996;320:871-7.

21. Jope RS, Yuskaitis CJ, Beurel E. Glycogen synthase kinase-3 (GSK3): inflammation, diseases, and therapeutics. Neurochem Res. 2007;32:577-95.

22. Rubio-Patiño C, Palmeri CM, Pérez-Perarnau A, Cosialls AM, Moncunill-Massaguer $C$, González-Gironès DM, et al. Glycogen synthase kinase- $3 \beta$ is involved in liganddependent activation of transcription and cellular localization of the glucocorticoid receptor. Mol Endocrinol. 2012;26:1508-20.

23. Galliher-Beckley AJ, Williams JG, Collins JB, Cidlowski JA. Glycogen synthase kinase 3beta-mediated serine phosphorylation of the human glucocorticoid receptor redirects gene expression profiles. Mol Cell Biol. 2008;28:7309-22.

24. Roma LP, Oliveira CA, Carneiro EM, Albuquerque GG, Boschero AC, Souza KL. $\mathrm{N}$-acetylcysteine protects pancreatic islet against glucocorticoid toxicity. Redox Rep. 2011;16:173-80.

25. Dey A, Hao S, Wosiski-Kuhn M, Stranahan AM. Glucocorticoid-mediated activation of GSK3 $\beta$ promotes tau phosphorylation and impairs memory in type 2 diabetes. Neurobiol Aging. 2017;57:75-83.

26. Wallace AD, Cidlowski JA. Proteasome-mediated glucocorticoid receptor degradation restricts transcriptional signaling by glucocorticoids. J Biol Chem. 2001;276:42714-21.

27. Rafacho A, Ortsäter H, Nadal A, Quesada I. Glucocorticoid treatment and endocrine pancreas function: implications for glucose homeostasis, insulin resistance and diabetes. J Endocrinol. 2014;223:R49-62.

28. Pasieka AM, Rafacho A. Impact of glucocorticoid excess on glucose tolerance: clinical and preclinical evidence. Metabolites 2016;6:24.

29. Kuo T, McQueen A, Chen TC, Wang JC. Regulation of glucose homeostasis by glucocorticoids. Adv Exp Med Biol. 2015;872:99-126.

30. Delfs N, Struja T, Gafner S, Muri T, Baechli C, Schuetz P, et al. Outcomes of hospitalized patients with glucocorticoid-induced hyperglycemia-A retrospective analysis. J Clin Med. 2020;9:4079.

31. Mazziotti G, Gazzaruso C, Giustina A. Diabetes in Cushing syndrome: basic and clinical aspects. Trends Endocrinol Metab. 2011;22:499-506.

32. Delaunay F, Khan A, Cintra A, Davani B, Ling ZC, Andersson A, et al. Pancreatic beta cells are important targets for the diabetogenic effects of glucocorticoids. J Clin Invest. 1997;100:2094-8.

33. Ullrich S, Berchtold S, Ranta F, Seebohm G, Henke G, Lupescu A, et al. Serum- and glucocorticoid-inducible kinase 1 (SGK1) mediates glucocorticoid-induced inhibition of insulin secretion. Diabetes 2005;54:1090-9.

34. Reich E, Tamary A, Sionov RV, Melloul D. Involvement of thioredoxin-interacting protein (TXNIP) in glucocorticoid-mediated beta cell death. Diabetologia 2012;55:1048-57.

35. Esguerra JLS, Ofori JK, Nagao M, Shuto Y, Karagiannopoulos A, Fadista J, et al. Glucocorticoid induces human beta cell dysfunction by involving riborepressor GAS5 LincRNA. Mol Metab. 2020;32:160-7.

36. Fine NHF, Doig CL, Elhassan YS, Vierra NC, Marchetti $P$, Bugliani M, et al. Glucocorticoids reprogram $\beta$-cell signaling to preserve insulin secretion. Diabetes 2018;67:278-90.

37. Liu X, Turban S, Carter RN, Ahmad S, Ramage L, Webster SP, et al. $\beta$-Cell-specific glucocorticoid reactivation attenuates inflammatory $\beta$-cell destruction. Front Endocrinol (Lausanne). 2014;5:165.
38. Guo B, Zhang W, Xu S, Lou J, Wang S, Men X. GSK-3 $\beta$ mediates dexamethasoneinduced pancreatic $\beta$ cell apoptosis. Life Sci. 2016;144:1-7.

39. Rojas J, Chávez-Castillo $M$, Chávez-Castillo $M$, Cabrera M, Cabrera M, Bermúdez V, et al. Glucococorticoid-induced death of pancreatic Beta cells: an organized chaos. JOP 2015;16:11-9.

40. Kaiser G, Gerst F, Michael D, Berchtold S, Friedrich B, Strutz-Seebohm N, et al. Regulation of forkhead box $\mathrm{O} 1$ (FOXO1) by protein kinase $\mathrm{B}$ and glucocorticoids: different mechanisms of induction of beta cell death in vitro. Diabetologia 2013;56:1587-95.

41. Suksri K, Semprasert N, Junking M, Kutpruek S, Limjindaporn T, Yenchitsomanus PT, et al. Dexamethasone induces pancreatic $\beta$-cell apoptosis through upregulation of TRAIL death receptor. J Mol Endocrinol. 2021;67:95-106.

42. Nuutinen U, Ropponen A, Suoranta S, Eeva J, Eray $M$, Pellinen R, et al. Dexamethasone-induced apoptosis and up-regulation of Bim is dependent on glycogen synthase kinase-3. Leuk Res. 2009;33:1714-7.

43. Rogatsky I, Waase CL, Garabedian MJ. Phosphorylation and inhibition of rat glucocorticoid receptor transcriptional activation by glycogen synthase kinase-3 (GSK-3). Species-specific differences between human and rat glucocorticoid receptor signaling as revealed through GSK-3 phosphorylation. J Biol Chem. 1998;273:14315-21.

44. Ullrich S, Zhang Y, Avram D, Ranta F, Kuhl D, Häring HU, et al. Dexamethasone increases $\mathrm{Na}+/ \mathrm{K}+$ ATPase activity in insulin secreting cells through SGK1. Biochem Biophys Res Commun. 2007;352:662-7.

45. Spokoini R, Kfir-Erenfeld S, Yefenof E, Sionov RV. Glycogen synthase kinase-3 plays a central role in mediating glucocorticoid-induced apoptosis. Mol Endocrinol. 2010;24:1136-50.

46. Pitasi CL, Liu J, Gausserès B, Pommier G, Delangre E, Armanet M, et al. Implication of glycogen synthase kinase 3 in diabetes-associated islet inflammation. J Endocrinol. 2020;244:133-48.

47. Figeac F, Uzan B, Faro M, Chelali N, Portha B, Movassat J. Neonatal growth and regeneration of beta-cells are regulated by the Wnt/beta-catenin signaling in normal and diabetic rats. Am J Physiol Endocrinol Metab. 2010;298:E245-56.

48. Figeac $F$, llias A, Bailbe D, Portha B, Movassat J. Local in vivo GSK3 $\beta$ knockdown promotes pancreatic $\beta$ cell and acinar cell regeneration in $90 \%$ pancreatectomized rat. Mol Ther. 2012;20:1944-52.

49. Liu Y, Tanabe K, Baronnier D, Patel S, Woodgett J, Cras-Méneur C, et al. Conditional ablation of Gsk-3 $\beta$ in islet beta cells results in expanded mass and resistance to fat feeding-induced diabetes in mice. Diabetologia 2010;53:2600-10.

50. Tanabe K, Liu Z, Patel S, Doble BW, Li L, Cras-Méneur C, et al. Genetic deficiency of glycogen synthase kinase-3beta corrects diabetes in mouse models of insulin resistance. PLoS Biol. 2008;6:e37.

51. Gesina E, Tronche F, Herrera P, Duchene B, Tales W, Czernichow $P$, et al. Dissecting the role of glucocorticoids on pancreas development. Diabetes 2004;53:2322-9.

52. Yan $\mathrm{C}$, Yang $\mathrm{H}$, Wang $\mathrm{Y}$, Dong $\mathrm{Y}, \mathrm{Yu} \mathrm{F}, \mathrm{Wu} \mathrm{Y}$, et al. Increased glycogen synthase kinase-3 $\beta$ and hexose-6-phosphate dehydrogenase expression in adipose tissue may contribute to glucocorticoid-induced mouse visceral adiposity. Int J Obes. 2016;40:1233-41.

53. Deng S, Dai G, Chen S, Nie Z, Zhou J, Fang H, et al. Dexamethasone induces osteoblast apoptosis through ROS-PI3K/AKT/GSK3 $\beta$ signaling pathway. Biomed Pharmacother. 2019;110:602-8.

54. Garza JC, Guo M, Zhang W, Lu XY. Leptin restores adult hippocampal neurogenesis in a chronic unpredictable stress model of depression and reverses glucocorticoid-induced inhibition of GSK-3 $\beta / \beta$-catenin signaling. Mol Psychiatry. 2012;17:790-808.

55. Smith E, Coetzee GA, Frenkel B. Glucocorticoids inhibit cell cycle progression in differentiating osteoblasts via glycogen synthase kinase-3beta. J Biol Chem. 2002;277:18191-7.

56. Webster JC, Jewell CM, Bodwell JE, Munck A, Sar M, Cidlowski JA. Mouse glucocorticoid receptor phosphorylation status influences multiple functions of the receptor protein. J Biol Chem. 1997;272:9287-93.

57. Beurel E, Jope RS. Glycogen synthase kinase-3 regulates inflammatory tolerance in astrocytes. Neuroscience 2010;169:1063-70.

58. Cuzzocrea S, Mazzon E, Di Paola R, Muià C, Crisafulli C, Dugo L, et al. Glycogen synthase kinase-3beta inhibition attenuates the degree of arthritis caused by type II collagen in the mouse. Clin Immunol. 2006;120:57-67.

59. Whittle BJ, Varga C, Pósa A, Molnár A, Collin M, Thiemermann C. Reduction of experimental colitis in the rat by inhibitors of glycogen synthase kinase-3beta. $\mathrm{Br}$ J Pharm. 2006;147:575-82.

60. Cheng Y, Pardo M, Armini RS, Martinez A, Mouhsine H, Zagury JF, et al. Stressinduced neuroinflammation is mediated by GSK3-dependent TLR4 signaling that promotes susceptibility to depression-like behavior. Brain Behav Immun. 2016;53:207-22.

61. Liu JJ, Raynal S, Bailbé D, Gausseres B, Carbonne C, Autier V, et al. Expression of the kynurenine pathway enzymes in the pancreatic islet cells. Activation by cytokines and glucolipotoxicity. Biochim Biophys Acta. 2015;1852:980-91. 
62. Ricordi C, Lacy PE, Finke EH, Olack BJ, Scharp DW. Automated method for isolation of human pancreatic islets. Diabetes 1988;37:413-20.

63. Bucher P, Mathe Z, Morel P, Bosco D, Andres A, Kurfuest M, et al. Assessment of a novel two-component enzyme preparation for human islet isolation and transplantation. Transplantation 2005;79:91-7.

\section{ACKNOWLEDGEMENTS}

We thank the Vectorology Platform-UMR7216 Epigenetic and Cell Fate center, and specially Christophe HURET, for access to instruments and technical advice. Confocal images were acquired at "Plateau Imagerie ». Unit of Functional and Adaptative Biology (BFA), Université de Paris, France. We thank Dr. Benjamin Uzan for helpful discussion for flow cytometry experiments. JM's research is supported by CNRS and Université de Paris. This project was partly supported by a MSDAVENIR grant to JM. ED is a recepient of a doctoral fellowship from the French Ministery of Higher Education and Research.

\section{AUTHOR CONTRIBUTIONS}

$\mathrm{JM}$ and ED designed the study. ED, JL, ST, KM, GP, DB were in charge of the acquisition and analysis of the data. MA and PC prepared human islets. JM and ED wrote the manuscript. ED and JL generated figures. Funds were obtained by JM.

\section{ETHICS STATEMENT}

All experiments involving animals were conducted in accordance with the European Community Council directives (2010/63/UE) and approved by the institutional Animal Care and Use Ethical Committee of the Paris-Diderot University (Agreement B-75-1317). Human pancreatic islets were isolated from the pancreases of brain-dead nondiabetic donors with prior consent for research use (after informed consent from the donor's family) in agreement with the French regulation "Agence de la Biomédecine" (registration number: PFS12-006) and the "Ministère de l'Enseignement supérieur et de la Recherche" (registration number: AC-2020-4101).

\section{COMPETING INTERESTS}

The authors declare no competing interests.

\section{ADDITIONAL INFORMATION}

Supplementary information The online version contains supplementary material available at https://doi.org/10.1038/s41419-021-04419-8.

Correspondence and requests for materials should be addressed to Jamileh Movassat.

Reprints and permission information is available at http://www.nature.com/ reprints

Publisher's note Springer Nature remains neutral with regard to jurisdictional claims in published maps and institutional affiliations.

(i) Open Access This article is licensed under a Creative Commons Attribution 4.0 International License, which permits use, sharing, adaptation, distribution and reproduction in any medium or format, as long as you give appropriate credit to the original author(s) and the source, provide a link to the Creative Commons license, and indicate if changes were made. The images or other third party material in this article are included in the article's Creative Commons license, unless indicated otherwise in a credit line to the material. If material is not included in the article's Creative Commons license and your intended use is not permitted by statutory regulation or exceeds the permitted use, you will need to obtain permission directly from the copyright holder. To view a copy of this license, visit http://creativecommons. org/licenses/by/4.0/.

(c) The Author(s) 2021 